\title{
Dynamic transcription programs during ES cell differentiation towards mesoderm in serum versus serum-free ${ }^{B M P 4}$ culture Stephen J Bruce ${ }^{1,2}$, Brooke B Gardiner ${ }^{1,3,4}$, Les J Burke ${ }^{1,4}$, M Milena Gongora ${ }^{1,3}$, Sean M Grimmond ${ }^{1,3,4}$ and Andrew C Perkins*1,2,3,4
}

\author{
Address: ${ }^{1}$ Institute for Molecular Bioscience, University of Queensland, Brisbane, Queensland, Australia, ${ }^{2}$ Wesley Research Institute, Queensland, \\ Australia, ${ }^{3}$ ARC Special Research Centre in Functional and Applied Genomics, Australia and ${ }^{4}$ Australian Stem Cell Centre, Melbourne, Australia \\ Email: Stephen J Bruce - s.bruce@imb.uq.edu.au; Brooke B Gardiner - b.gardiner@imb.uq.edu.au; Les J Burke - l.burke@imb.uq.edu.au; M \\ Milena Gongora - m.gongora@imb.uq.edu.au; Sean M Grimmond - s.grimmond@imb.uq.edu.au; \\ Andrew C Perkins* - a.perkins@imb.uq.edu.au \\ * Corresponding author
}

Published: 10 October 2007

BMC Genomics 2007, 8:365 doi:10.1/86/|47|-2/64-8-365
Received: 28 May 2007

Accepted: 10 October 2007

This article is available from: http://www.biomedcentral.com/I47I-2/64/8/365

(c) 2007 Bruce et al; licensee BioMed Central Ltd.

This is an Open Access article distributed under the terms of the Creative Commons Attribution License (http://creativecommons.org/licenses/by/2.0), which permits unrestricted use, distribution, and reproduction in any medium, provided the original work is properly cited.

\begin{abstract}
Background: Expression profiling of embryonic stem (ES) cell differentiation in the presence of serum has been performed previously. It remains unclear if transcriptional activation is dependent on complex growth factor mixtures in serum or whether this process is intrinsic to ES cells once the stem cell program has been inactivated. The aims of this study were to determine the transcriptional programs associated with the stem cell state and to characterize mesoderm differentiation between serum and serum-free culture.

Results: ES cells were differentiated as embryoid bodies in 10\% FBS or serum-free media containing BMP4 (2 ng/ml), and expression profiled using $47 \mathrm{~K}$ Illumina(R) Sentrix arrays. Statistical methods were employed to define gene sets characteristic of stem cell, epiblast and primitive streak programs. Although the initial differentiation profile was similar between the two culture conditions, cardiac gene expression was inhibited in serum whereas blood gene expression was enhanced. Also, expression of many members of the Kruppel-like factor (KLF) family of transcription factors changed dramatically during the first few days of differentiation. KLF2 and KLF4 co-localized with OCT4 in a sub-nuclear compartment of ES cells, dynamic changes in KLF-DNA binding activities occurred upon differentiation, and strong bio-informatic evidence for direct regulation of many stem cell genes by KLFs was found.

Conclusion: Down regulation of stem cell genes and activation of epiblast/primitive streak genes is similar in serum and defined media, but subsequent mesoderm differentiation is strongly influenced by the composition of the media. In addition, KLF family members are likely to be important regulators of many stem cell genes.
\end{abstract}

\section{Background}

Embryonic stem (ES) cells isolated from the inner cell mass of the early mammalian blastocyst-stage embryo retain pluripotency when cultured on mouse embryonic fibroblasts (MEFs) in the presence of leukemia inhibitory factor (LIF) [1]. In the absence of LIF and MEF attachment, ES cells spontaneously differentiate into multi-cellular aggregates termed embryoid bodies (EBs). Although the 
spatial complexity of organogenesis is not established during EB maturation, the dynamics of gene expression closely mimic those which characterize early stages of mouse development [2-5]. Thus, ES cell differentiation is an excellent model system for the discovery of genes involved in developmental processes.

Many studies have attempted to identify genes that define the stem cell state by mining for genes co-expressed in ES cells and various other stem cell populations such as hematopoietic and neural stem cells [6,7], or ES cells and trophoblast stem cells [8]. Some of these studies have been criticized because they were unable to define a similar cohort of stem cell genes [9]. Also, this approach is likely to find co-expression of 'housekeeping' genes that are irrelevant to the stem cell state. More recently, dynamic expression profiling during ES cell differentiation has been undertaken using various EB culture techniques $[10,11]$ and the addition of exogenous growth factors [7]. Most of these studies followed differentiation for a short time period (up to 6-8 days) due to inherent limitations of liquid or adherent cultures cell differentiation systems.

Various platforms have been used to determine gene expression profiles, including differential display, SAGE [12] and slide micro-arrays, such as those provided by Affymetrix, Agilent and Compugen. In this study we employed Illumina ${ }^{\circledR}$ Sentrix Mouse- 6 oligo bead arrays [13], which have $\sim 47 \mathrm{~K}$ probes that are largely based on the MEEBO set of transcripts, plus ESTs discovered as part of the FANTOM2 transcriptome project [14], some alternatively employed exons, and a small subset of non-coding transcripts. This is a new, rich and sensitive platform for expression profiling [15].

ES cells were differentiated in methylcellulose cultures, which allowed consistent EB development over 16 days in either serum $[2,16]$ or defined serum-free media containing BMP4 (2 ng/ml), termed serum-free ${ }^{\mathrm{B} 4 \mathrm{~L}}$ hereafter [17]. The dynamics of loss of stem cell gene expression and activation of epiblast and primitive streak gene expression programs were similar in serum and serum-free ${ }^{\mathrm{B} 4 \mathrm{~L}}$ but QT clustering revealed a significant difference in mesoderm outcomes from day 6 onwards. In particular, cardiac gene expression was greater in serum-free ${ }^{\mathrm{B} 4 \mathrm{~L}}$ whereas activation of the blood program was enhanced in serum.

High expression levels of Kruppel-like factor (KLF) family members: Klf2, Klf4, Klf5 and Klf9 was detected in undifferentiated ES cells, and confirmed by quantitative real time RT-PCR, indirect immuno-fluorescence and DNAbinding assays. Expression was down regulated rapidly upon differentiation and a different set of $K l f s$ : Klf3, Klf16 and $K l f 1 / E k l f$, were activated upon ES cell differentiation.
Also, KLF-binding sites were markedly over represented in the proximal promoters of most stem cell specific genes, suggesting possible direct regulation by KLFs. We suggest a model in which the balance between self-renewal and differentiation is regulated by competitive occupancy of the proximal promoters of key stem cell genes such as Zfp42/Rex-1, Nanog,Pou5f1(Oct4), Lefty1 and Lefty2, and others such as the Klf genes themselves.

\section{Results \\ Differentiation of ES cells in serum and serum-free ${ }^{B 4 L}$ culture}

The directed differentiation of embryonic stem cells into desirable cell types will depend upon the addition of specific growth factors to defined media and reproducible physical conditions of culture. To establish a baseline for such studies, we undertook a comparison of murine ES cell differentiation using an embryoid body (EB) methylcellulose culture system containing either 10\% FBS [2] or a chemically defined BSA-based media containing $2 \mathrm{ng} /$ $\mathrm{ml}$ of BMP4, termed serum-free ${ }^{\mathrm{B} 4 \mathrm{~L}}$ [17]. Triplicate experiments were performed in which ES cells were harvested after feeder depletion, and set up in parallel EB cultures in serum versus serum-free ${ }^{\mathrm{B} 4 \mathrm{~L}}$. RNA was collected at regular intervals up to 16 days, quantitative RT-PCR was performed on a panel of genes representing defined stages of development to establish the robustness of the culture system (Figure 1), and expression profiling was performed using Illumina ${ }^{\circledR}$ Sentrix Mouse- 6 bead arrays (see Methods and [13]).

Changes in gene expression were extremely reproducible across ES differentiation experiments with overall correlation of global gene expression for biological replicates in the order or $0.95-0.96$. Approximately $30 \%$ of the probes were differentially expressed at one or more stages of EB differentiation as determined by one-way Welch ANOVA with multiple testing corrections using the Benjamini and Hochberg False Discovery Rate algorithm (7,967 probes with a p-value of $<0.01$ by Welch t-test) (Figure $2 \mathrm{~A}$ ).

To mine for genes with similar patterns of expression across the time course, hierarchical clustering was performed on the 7,967 probes and represented graphically. A large percentage of these $(\sim 30 \%)$ displayed highest expression in undifferentiated ES cells and subsequent reduced expression over time (labeled stem in Figure 2B). A second major cluster showed marked induction after day 4-6 of differentiation (labeled mesoderm in Figure 2B).

\section{Putative stem cell genes sets}

Previous studies have identified genes important to the stem cell state by comparing expression profiling data from different stem cell populations such as ES cells, hae- 

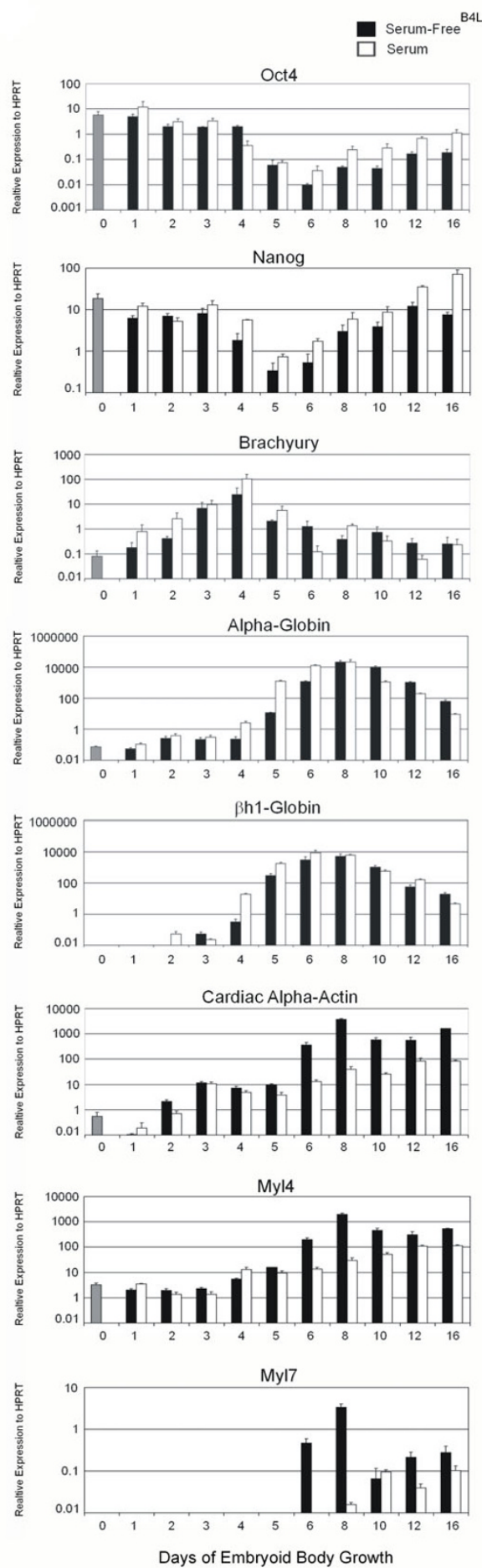

\section{Figure I}

Dynamic gene expression during EB differentiation in serum and serum-free media containing BMP4 [2 ng/ $\mathrm{ml}$. Expression of stem cell, primitive streak and late mesoderm genes were analysed by quantitative RT-PCR in undifferentiated ES cells ( 0 , grey bar) and in EBs collected for up to 16 days in serum (white bars) or defined media (black bars) from the same starting ES cell populations. Bars represent the means of three (serum) or two (serum-free ${ }^{\mathrm{B} 4 \mathrm{~L}}$ ) biological replicates. The Y-axis represents a log scale normalized relative to the housekeeping gene HPRT. Error bars indicate standard deviation. 
A
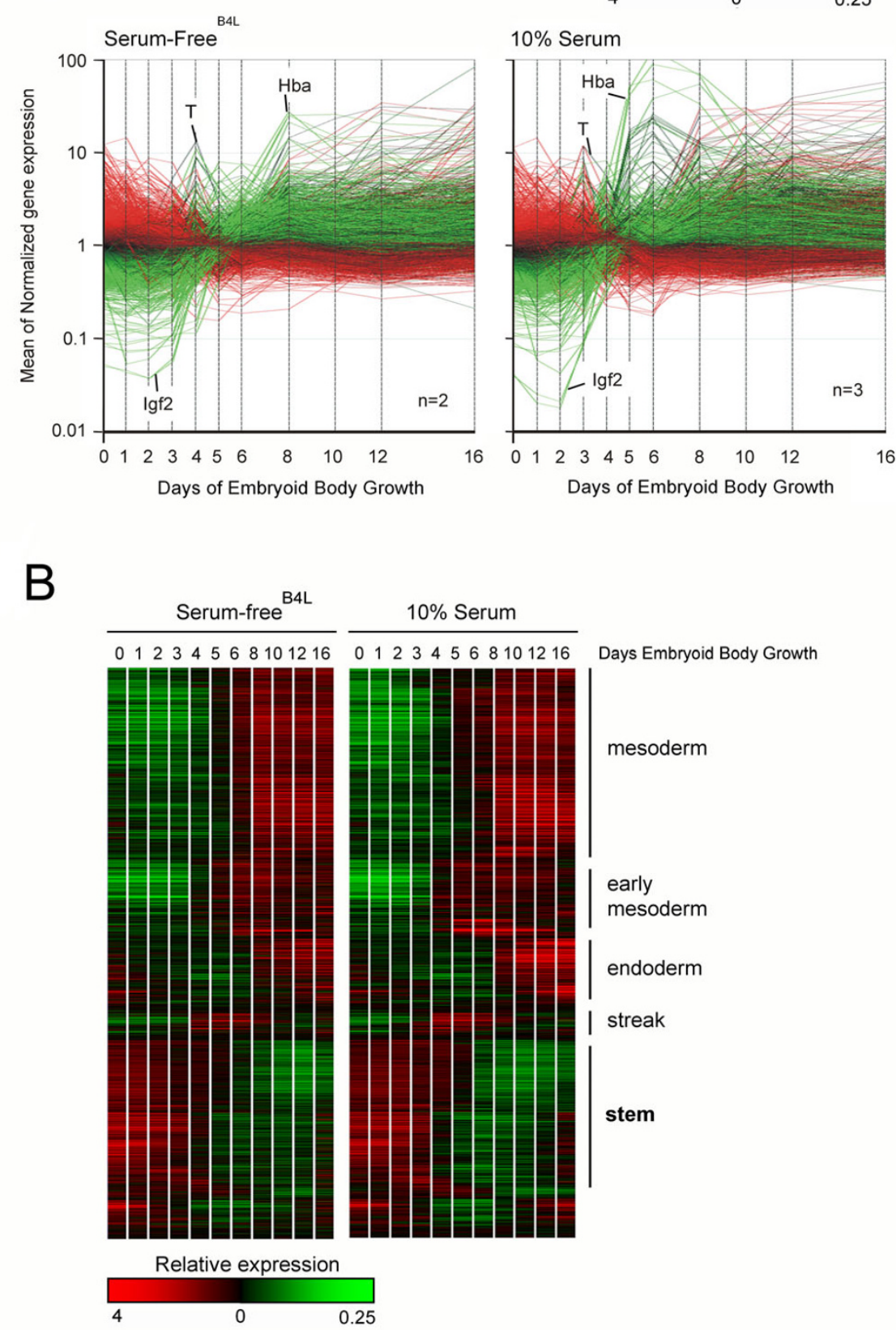

Figure 2

Gene expression profiles during 16 days of EB differentiation in serum and serum-free media containing BMP4 [2 ng/ml]. (A) GeneSpring representation of the subset of genes from the $48 \mathrm{~K}$ Illumina array that showed significant differences in gene expression at 2 or more time points. Each line represents the mean normalised expression of an individual Illumina probe. Colours represent relative expression (red $4 \times$ increased; green $0.25 \times$ reduced) compared to a gene mean of I (black) with expression in undifferentiated ES cells (day 0 ) as the decision point for colour coding. The expression profiles of $\mathrm{T}$ (brachyury), $\mathrm{Hba}(\alpha$-globin), and Igf2 are indicated for reference. (B) Clustering (tree) of the genes that showed significant $(\mathrm{p}<$ 0.01 ) changes in gene expression upon differentiation by One-way Welch ANOVA. Expression levels are heat map colour coded (inset) with high expression at Day 0 coloured red and low expression coloured green. 
matopoietic stem cells (HSCs) and neural stem cells $[6,18]$. We used two alternative approaches to identify specific stem cell specific gene expression. Firstly, genes with dynamic expression patterns which correlated closely with Oct4, Sox2 or Nanog expression profiles (Pearson correlation $>0.9$ ) were determined as previously described $[6,7]$. Second, genes rapidly down regulated $\geq 3$ fold by day 3 of differentiation, a time point where ES cell clonogenicity decreases dramatically, were determined. Not surprisingly there was very little overlap between these gene lists, primarily because Oct4 and Nanog expression persists during EB differentiation longer than many other stem cell genes (Figure 1). Full lists of genes ranked according to similarity of expression (Pearson correlation $>0.9$ ) with expression patterns for Oct4, Nanog or Sox2 are provided in Additional files 1, 2, 3, respectively.

Only fifty-nine genes were down regulated $\geq 3$ fold by day 3 of EB differentiation (Table 1). Many of these have been identified as stem cell markers by other groups using alternative strategies $[6,7,19]$. Information was compiled on their known expression patterns and/or gene knockout phenotypes via literature searches as referenced in Table 1. Insufficient space exists to discuss every gene and most have been previously identified as ES cell enriched transcripts. Osteopontin is secreted by osteoblasts in the bone marrow niche where it is thought to play an important role in the maintenance of HSC quiescence and maintenance of 'stemness' [20]. It has also been discovered by other groups as a strong marker of ES cells and is regulated directly by the key stem cell transcription factors, Oct4 and Sox2 [21]. Thus, osteopontin is likely to be a useful marker of ES cell pluripotency and may play autocrine or paracrine roles in maintenance of stemness. The second most rapidly down regulated gene was estrogen related receptor $\beta$, Esrrb, which had previously been identified as a stem cell specific gene and shown to be critical for maintenance of the stem cell state [19]. F-box 15 (Fbxo15), a member of the large F-box family of genes [22] was also rapidly down regulated. Fbxo15 is known to be highly expressed in ES cells, is regulated by Oct 4 and Sox2, but is dispensable for ES cell self-renewal [23]. Recently, the stem cell specificity of this locus was used to screen for cDNAs capable of transforming mouse fibroblasts into ES cell populations [24]. Other notable rapidly down regulated genes included the nodal inhibitors Lefty- 1 and Lefty-2, and Zfp42/Rex-1, which are also well established as stem cell markers [19].

Oct4, Nanog and Sox2 are not included in Table 1, even though each is required for the maintenance of ES cell pluripotency [25-27] due to their persistent expression during the first 3 days of EB differentiation (Figure 1 and $5 \mathrm{~A}$, and Additional file 1). Indeed, Oct4 expression is known to persist beyond the inner cell mass stage of development in vivo, with transcripts detected in the epiblast and later in the primitive streak, before it becomes further restricted to primordial germ cells $[10,28]$. 779 genes with a similar pattern of expression to Oct4 (Pearson correlation of $>0.9$ ) were identified (Additional file 1 ). As expected this list also includes many well known stem cell genes such as Sal-like 1, nodal, chromobox homolog 7 (Cbx7), Dnmt3b and Sprouty homolog 4 [19]. We also mined for stem cell genes by looking for similarity (Pearson correlation of $>0.9$ ) with Nanog and Sox2 gene expression profiles. These provided overlapping but not identical sets of putative stem cell specific genes (Additional files 2, 3). Full data for the 16 days of differentiation can be interrogated and mined for specific differentiation outcomes via Signet (Login_Bruce) (see Methods).

\section{Tightly co-ordinated waves of gene expression suggest sequential activation of epiblast, primitive streak and mesoderm differentiation programs}

Many alternative differentiation programs occur simultaneously during ES cell differentiation. Therefore, it is difficult to find gene syn-expression patterns that identify specific programs using standard clustering methods. An alternative approach is to search for expression patterns that closely resemble genes of known function. For example, the T box gene, brachyury, is a well characterized specific marker of the primitive streak [29]. Brachyury expression is transient in vivo, a feature recapitulated during ES cell differentiation [2]. Using qRT-PCR, brachyury was induced $\sim 1000$ fold from D0 to day 4 and then rapidly silenced to baseline levels by D6 (Figure 1). The dynamics of brachyury expression were similar between serum and serum-free ${ }^{\mathrm{B} 4 \mathrm{~L}}$ media (Figure 1 and $3 \mathrm{~A}$ ), but serum-free media was unable to support brachyury induction in the absence of BMP-4 (data not shown). Thus, BMP4 (or related factors in serum such as activin) is essential for mesoderm generation. Thirty genes were identified with a similar expression pattern to brachyury (Pearson correlation $>0.9$ ) (Table 2) including many genes with established expression or critical functions during primitive streak formation, such as Mix1 [30], Lim1 [31], Sp5 [32] and eomesodermin [33]. Transient expression of many of these 'streak-specific' genes was validated by qRT-PCR (Figure 3B and data not shown). In all cases there was a close correlation between the qRT-PCR results and the profiling data (Figure 3A).

Interestingly, four novel transcripts were identified in this list (Table 2). One of these, 8430415E04Rik, was detected by two independent probes, strongly supporting its 'streak-specific' expression; by qRT-PCR there was $~ 50$ fold induction from day 2 to day 3 of differentiation and a decrease to near baseline levels by day 6 (Figure 3B). The gene contains 24 exons, and the full length cDNA encodes 
Table I: Genes rapidly down regulated ( $>3$ fold in 3 days) upon ES cell differentiation

\begin{tabular}{|c|c|c|c|c|c|c|}
\hline Gene Name & Synonyms & Genbank ID & Fold $\downarrow$ D0 $\rightarrow$ D3 & Raw Do & Function & Refs \\
\hline Secreted phosphoprotein I & Osteopontin; Spp I & NM 009263 & 26.8 & 3588 & $\begin{array}{l}\text { Reg. by Oct } 4 \text { and } \\
\text { Sox } 2\end{array}$ & {$[21,96]$} \\
\hline Estrogen related receptor, beta & Err2; Estrrb; Nr3b2 & NM 011934 & 24.0 & 4238 & $\begin{array}{l}\text { ES cell renewal, } \\
\text { placenta }\end{array}$ & [97] \\
\hline F-box 15 & $\mathrm{Fbx} 15$ & NM 015798 & 21.8 & 4487 & $\begin{array}{l}\text { Stem cell specific } \\
\text { locus }\end{array}$ & {$[23]$} \\
\hline RIKEN cDNA 2200001115 & $220000 I I I 5 R i k$ & NM 183278 & 18.3 & 2780 & & \\
\hline Kruppel-like factor 2 & KIf2; LkIf & NM 008452 & 17.0 & 2639 & Vascular defect & [49] \\
\hline $\begin{array}{l}\text { Left-right determination, factor } \\
\text { B }\end{array}$ & Leftb; Stra3; Tgfb4; Lefty & NM 010094 & 14.4 & 2537 & $\begin{array}{l}\text { Nodal signalling } \\
\text { inhibitor }\end{array}$ & {$[87]$} \\
\hline Transcription factor CP2-like I & Crtr-I; LBP-9 & NM_023755 & 13.8 & 2237 & ES cells, repressor & [98] \\
\hline Zinc finger protein 42 & Rex-I; RexI; Zfp-42 & NM 009556 & 13.4 & 2108 & $\begin{array}{l}\text { Nanog-Sox } 2 \\
\text { induced }\end{array}$ & {$[99,100]$} \\
\hline L-threonine dehydrogenase & Tdh & NM 021480 & 10.9 & 1764 & $\begin{array}{l}\text { L-threonine } \\
\text { degradation }\end{array}$ & {$[101]$} \\
\hline $\begin{array}{l}\text { DNA (cytosine-5-)- } \\
\text { methyltransferase 3-like }\end{array}$ & D6Ertd I4e, Dnmt3I & NM_019448 & 10.8 & 5226 & Maternal imprinting & {$[102]$} \\
\hline $\begin{array}{l}\text { Transcription elongation factor } \\
\text { A, } 3\end{array}$ & S-II, Tcea3 & NM 011542 & 8.6 & 3874 & ICM Expression & {$[103]$} \\
\hline $\begin{array}{l}\text { Myosin light chain, skeletal } \\
\text { muscle }\end{array}$ & MLC-2; Mlc2, Mylpf & NM 016754 & 8.6 & 1560 & Cardiac muscle & {$[104]$} \\
\hline SI00 calcium binding protein A6 & Cacy, SI00a6, calcyclin & NM 011313 & 8.2 & 9086 & Cell cycle regulation & {$[105]$} \\
\hline Testis expressed gene 19 & TexI9, 24I008IM02Rik & NM 028602 & 8.1 & 1963 & Spermatogonia & {$[106]$} \\
\hline Epithelial membrane protein I & TMP, Empl & NM 010128 & 7.9 & 1030 & $\begin{array}{l}\text { Neuronal } \\
\text { differentiation }\end{array}$ & {$[107]$} \\
\hline $\begin{array}{l}\text { DNA segment, Chr I I, ERATO } \\
\text { Doi } 636\end{array}$ & DIIErtd636e & NM 029794 & 7.9 & 1278 & $\begin{array}{l}\text { Expressed in } \\
\text { Morula }\end{array}$ & {$[108]$} \\
\hline $\begin{array}{l}\text { Similar to solute carrier family } \\
7 \text {, member } 3\end{array}$ & Slc7a3 & NM 001004153 & 7.3 & 1036 & & \\
\hline $\begin{array}{l}\text { Left-right determination, factor } \\
2\end{array}$ & Lefta; Ebaf; Lefty 2 & NM 177099 & 7.2 & 1903 & Inhibitor of Nodal & [109] \\
\hline Junction adhesion molecule 2 & Jcam2; VE-JAM, Jam2 & NM 023844 & 6.5 & 713 & KO normal & {$[110]$} \\
\hline $\begin{array}{l}\text { Lysosomal-associated protein, } \\
\text { transmembrane } 5\end{array}$ & E3, Laptm5 & NM 010686 & 6.5 & 1539 & haematopoiesis & {$[111]$} \\
\hline Discoidin domain receptor I & DrrI, MCKI0, EDDRI & NM 007584 & 6.4 & 5451 & $\begin{array}{l}\text { Collagen response } \\
\text { receptor }\end{array}$ & {$\left[\begin{array}{lll}1 & 2\end{array}\right]$} \\
\hline $\begin{array}{l}\text { Aminoadipate-semialdehyde } \\
\text { synthase }\end{array}$ & Aass, LKR/SDH; Lorsdh & NM 013930 & 6.2 & 1094 & Mitochondria & {$\left[\begin{array}{lll}1 & 3\end{array}\right]$} \\
\hline RIKEN cDNA 24I 0039E07 & 24I0039E07Rik & NM 212483 & 6.2 & 737 & & \\
\hline RIKEN cDNA 24I0004A20 & 2410004 A20Rik & NM 025890 & 5.7 & 644 & & \\
\hline Gastrulation brain homeobox 2 & Gbx2, MMoxA;Stra7 & NM 010262 & 5.6 & 1204 & $\begin{array}{l}\text { Midbrain/hindbrain } \\
\text { organiser }\end{array}$ & {$[114]$} \\
\hline cDNA sequence $\mathrm{BC} 050188$ & $4933403 \mathrm{DI} / 4$ & NM 177742 & 5.6 & 497 & & \\
\hline Cordon-bleu & Cobl, C530045FI8Rik & NM 172496 & 5.1 & 619 & & \\
\hline Similar to EF IA & elF-IA, elF-4C & $X M \quad 181357$ & 5.0 & 538 & & \\
\hline Regulatory factor $\mathrm{X}, 2$ & $\mathrm{Rf} \times 2$ & NM 009056 & 4.9 & 796 & ICM expression & [103] \\
\hline $\begin{array}{l}\text { Tissue inhibitor of } \\
\text { metalloproteinase I }\end{array}$ & Clgi;Timp;TIMP-I & NM 011593 & 4.6 & 1732 & $\begin{array}{l}\text { Metalloproteinase } \\
\text { inhibitor matrix }\end{array}$ & {$[115]$} \\
\hline Kruppel-like factor 4 & KIf4, Gklf; Zie & NM 010637 & 4.5 & 597 & $\begin{array}{l}\text { Epidermal, gut } \\
\text { defect }\end{array}$ & {$[116]$} \\
\hline $\begin{array}{l}\text { Insulin-like growth factor } \\
\text { binding protein } 7\end{array}$ & Igfbp7, Fst12, mac25 & NM 008048 & 4.4 & 813 & & \\
\hline $\begin{array}{l}\text { latent transforming growth } \\
\text { factor BP4 }\end{array}$ & Ltbp4, 23 I0046A I 3Rik & NM 17564I & 4.4 & 481 & & \\
\hline $\begin{array}{l}\text { Dnaj (Hsp40) homolog, } \\
\text { subfamily C, } 6\end{array}$ & Dnajc6, 28I0027M23Rik & NM 198412 & 4.3 & 490 & & \\
\hline Kruppel-like factor 5 & KIf5, Bteb2, IKLF & NM 009769 & 4.3 & 1797 & $\begin{array}{l}\text { Cardiovascular } \\
\text { remodelling }\end{array}$ & {$[117]$} \\
\hline $\begin{array}{l}\text { Nuclear receptor subfamily } 5 \text {, } \\
\text { group A, } 2\end{array}$ & Nr5a2, Ftf;LRH-I & NM 030676 & 4.2 & 494 & $\begin{array}{l}\text { Ovary granulosa } \\
\text { cells }\end{array}$ & [1 18$]$ \\
\hline RIKEN cDNA D230005D02 & B230207J08 & NM 172813 & 4.2 & 433 & & \\
\hline Nuclear protein I & Nupr I, Com I;p8 & NM 019738 & 4.1 & 388 & KO normal & {$[119]$} \\
\hline
\end{tabular}


Table I: Genes rapidly down regulated ( $>3$ fold in 3 days) upon ES cell differentiation (Continued)

\begin{tabular}{|c|c|c|c|c|c|c|}
\hline Intercellular adhesion molecule & Icam I, CD54, Icam-I & NM 010493 & 4.1 & 716 & $\begin{array}{l}\text { KO normal, } \\
\text { inflammation }\end{array}$ & {$[120]$} \\
\hline $\begin{array}{l}\text { Interleukin-I receptor- } \\
\text { associated kinase } 3\end{array}$ & Irak3, IRAK-M & NM 028679 & 3.9 & 409 & $\begin{array}{l}\text { Immune } \\
\text { homeostasis }\end{array}$ & {$[|2|]$} \\
\hline $\begin{array}{l}\text { Keratin complex I, acidic, gene } \\
\text { I7 }\end{array}$ & KrtI-I7, KI7 & NM 010663 & 3.9 & 368 & $\begin{array}{l}\text { Embryonic } \\
\text { ectoderm }\end{array}$ & [122] \\
\hline Stathmin-like 2 & Stmn2, Scgn 10, Stmb2 & NM 025285 & 3.9 & 712 & $\begin{array}{l}\text { KO normal, cell } \\
\text { cycle }\end{array}$ & [123] \\
\hline $\begin{array}{l}\text { Suppressor of cytokine signaling } \\
3\end{array}$ & Socs3, CIS3, SSI-3 & NM 007707 & 3.8 & 1081 & LIF singalling & [124] \\
\hline Lipase, member $\mathrm{H}$ & Lpdlr; PLAIB Liph & NM 153404 & 3.8 & 446 & Lipid metabolism & [125] \\
\hline RIKEN cDNA 4933405K07 & 4930427IIIRik & NM 028913 & 3.8 & 573 & & \\
\hline $\begin{array}{l}\text { Erythrocyte protein band } 4.1 \text { - } \\
\text { like } 4 a\end{array}$ & Epb4.II4, NBL4 & NM 013512 & 3.8 & 809 & $\begin{array}{l}\text { beta-catenin/Tcf } \\
\text { pathway }\end{array}$ & [126] \\
\hline $\begin{array}{l}\text { Polo-like kinase } 3 \text { (Drosophila) } \\
\text { (Plk3) }\end{array}$ & Cnk, Fnk, PRK & NM 013807 & 3.7 & 567 & Mitosis regulator & [127] \\
\hline Heat shock protein I (HspbI) & 27 kDa, Hsp25 & NM 013560 & 3.7 & 3731 & $\begin{array}{l}\text { Blastocyst } \\
\text { expression }\end{array}$ & [128] \\
\hline RIKEN cDNA I70006IGI9 & I70006IGI9Rik & $\underline{X M \quad 140052}$ & 3.7 & 425 & & \\
\hline Mannosidase, beta A, lysosomal & Bmn, Manba & NM 027288 & 3.7 & 484 & $\begin{array}{l}\text { Glycoprotein } \\
\text { cleavage, KO } \\
\text { normal }\end{array}$ & [129] \\
\hline $\begin{array}{l}\text { Developmental pluripotency- } \\
\text { associated } 3\end{array}$ & PCG7, Stella, Dppa3 & NM 139218 & 3.6 & 450 & $\begin{array}{l}\text { Expressed in } \\
\text { preimplantation } \\
\text { embryos }\end{array}$ & [130] \\
\hline Lysyl oxidase & TSC-160, Lox & NM 010728 & 3.6 & 644 & $\begin{array}{l}\text { KO cardiovascular } \\
\text { defects }\end{array}$ & {$[131]$} \\
\hline RIKEN cDNA EI 300 I 4J05 & Tet2 & NM 145989 & 3.5 & 866 & & \\
\hline Myeloblastosis oncogene-like 2 & B-myb, Mybl2 & NM 008652 & 3.3 & 718 & $\begin{array}{l}\text { Cell proliferation } \\
\text { GI/S transition }\end{array}$ & [132] \\
\hline $\begin{array}{l}\text { Pleckstrin homology domain } \\
\text { containing, A4 }\end{array}$ & PEPPI, Plekha4 & NM 148927 & 3.3 & 532 & $\begin{array}{l}\text { Preimplantation } \\
\text { embryo expression }\end{array}$ & [108] \\
\hline Aurora kinase C (Aurkc) & AlK3, StkI3 & NM 020572 & 3.3 & 305 & $\begin{array}{l}\text { Chromosome } \\
\text { segregation }\end{array}$ & [133] \\
\hline $\begin{array}{l}\text { Fibroblast growth factor binding } \\
\text { protein I }\end{array}$ & FGF-BP, Fgfbpl & NM 008009 & 3.1 & 312 & $\begin{array}{l}\text { Enhances FGF } \\
\text { activity }\end{array}$ & [134] \\
\hline Caveolin, caveolae protein I & Cavl & NM 007616 & 3.1 & 438 & $\begin{array}{l}\text { KO viable, vascular } \\
\text { defects }\end{array}$ & [135] \\
\hline
\end{tabular}

for a protein of 868 amino acids (Figure 3D) which is highly conserved in vertebrates (Additional file 4). It has little homology to other proteins apart from three predicted HEAT domains or armadillo domains (grey shading in Figure 3D). Drosophila armadillo interacts with $\beta$-catenin via its HEAT/armadillo repeat [34], which suggests the protein encoded by 8430415E04Rik may also be involved in protein-protein interactions.

The list of primitive streak genes in table 2 is smaller than that previously published [10] due to the very stringent criteria used to determine brachyury-like patterns of expression. Thus, to find further genes characteristic of epiblast, early and late primitive streak programs, probes were identified which were transiently up and down regulated at least two fold with peak expression at day 2, 3 or 4 of EB differentiation. Gene lists were combined (102 Illumina probes) and clustered into epiblast, early, mid and late streak groups plus a unique group in which expression was very transient at day 3 of differentiation (designated 'brief' at the bottom of Figure 3C). Also, lists were generated by searching for similarity of dynamic expression profiles to known genes which are accepted specific markers of specific stages of mouse development. For example, Fgf5 is specifically expressed in the epiblast [35], and Wnt5a is expressed in the late primitive streak [36]. The Fgf5-like (epiblast) list includes the methyltransferase, Dnmt3b, which was massively up-regulated in the first 2 days of EB differentiation (Additional file 5) and is known to be essential for mesoderm differentiation [37]. This list also includes Pim2, Zic2, Wnt8a, the SP1 (and possibly SP5) cofactor Crsp2, and Irf1. The Wnt5a-like (late primitive streak) list contains 76 genes including many homeobox genes (Hoxb2, Hoxd1, Hoxb6 and Hox8/ Msx2), Cdx2, Hand1, Tbx3, Bmp4 and the VEGF receptor Flt1 (Additional file 6). Many are expressed at E10 of mouse development in the remnants of the primitive streak [36], suggesting the Wnt5a-like list includes many genes known to pattern the embryo following formation of the germ layers. There is a significant overlap between 


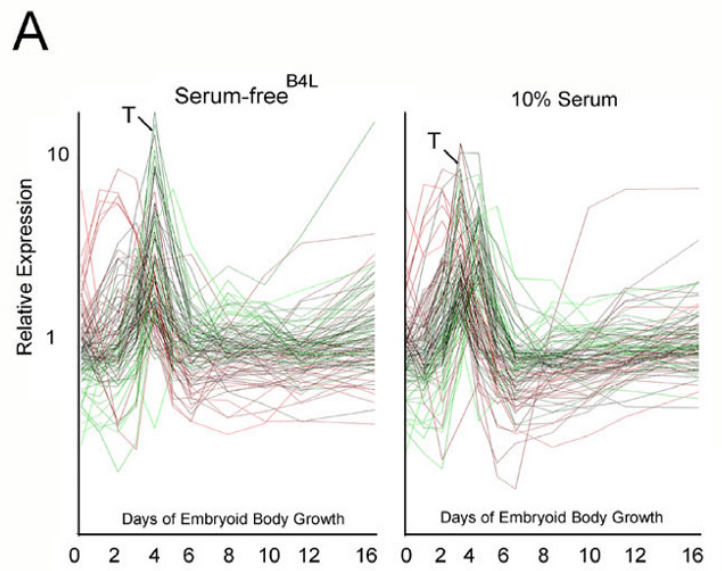

C
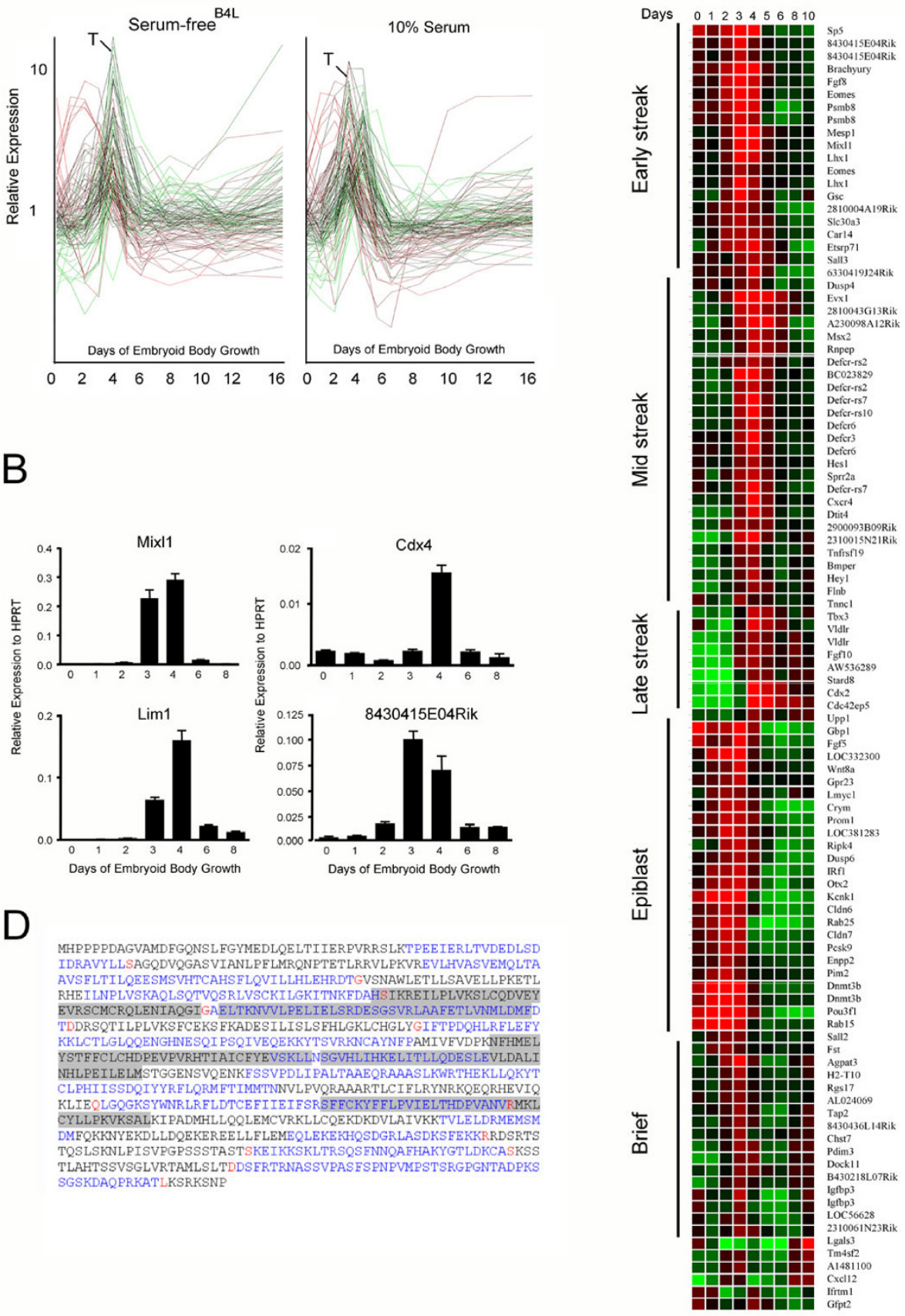

Figure 3

Mining for genes expressed in patterns consistent with primitive streak, and epiblast differentiation programs. (A) GeneSpring representation of epiblast and streak gene expression profiles during EB differentiation in $10 \%$ serum or serum-free ${ }^{\mathrm{B} L \mathrm{~L}}$ culture. The up-regulation of genes between days $2-4$ were similar under both conditions. (B) $\mathrm{qRT}$-PCR analysis of Mixl, Lim I, Cdx4 and Riken clone 84304I5E04Rik. The Y-axis represents expression relative to the housekeeping gene HPRT. Error bars indicate \pm SD from three biological replicates. (C) 102 genes transiently up regulated during the first 4 days of ES cell differentiation were clustered using a tree algorithm and Pearson correlation of $>0.9$. The 'Brief' group represents gene with very transient expression at day 3. (D) Coding region for 84304I5E04Rik. The shaded areas represent the three Heat domains. 
Table 2: Brachyury-like (Primitive Streak) gene list (Pearson correlation $>0.9$ with brachyury)

\begin{tabular}{|c|c|c|c|c|c|}
\hline Description & Symbol & Corr. & Synonyms & Genbank ID & Expression/Function \\
\hline Brachyury (T) & $\mathrm{T}$ & 1.00 & cou;Low;Lr;;TI & NM 009309.1 & {$[33,136]$ Primitive streak } \\
\hline Eomesodermin * & Eomes & 0.98 & Tbr2 & NM 010136.1 & [33] Primitive streak \\
\hline Fibroblast growth factor 8 & Fgf8 & 0.97 & Aig;;Fgf-8 & NM 010205.1 & [137] primitive streak expression \\
\hline Mixl & Mixll & 0.97 & Mml;Mml & NM 013729.2 & $\begin{array}{l}\text { [30] KO primitive streak } \\
\text { abnormal }\end{array}$ \\
\hline Lysophospholipase isoform I & A530050D06Rik & 0.97 & & $\underline{X M ~ 203596}$ & \\
\hline LIM homeobox protein I* & LhxI & 0.96 & Lim I; LhxI & NM 008498 & [3I] Primitive streak expression \\
\hline Mesoderm posterior I & Mespl & 0.95 & & NM 008588.1 & [138] nascent mesodermal cells \\
\hline Sp5 & Sp5 & 0.94 & & NM 022435.2 & [32] Primitive streak expression \\
\hline 84304I5E04Rik* & 84304I5E04Rik & 0.94 & unknown & NM 028980.1 & \\
\hline Axin2 & Axin2 & 0.94 & Axil;Axil;Conductin & NM 015732.3 & [139] Wnt signalling inhibitor \\
\hline Ninein & $\mathrm{Nin}$ & 0.93 & mKIAAI565 & NM_008697 & [140] Centrosome anchoring \\
\hline E330009J07Rik & E330009j07Rik & 0.93 & mKIAAII 47 & NM 175528 & \\
\hline Proteosome subunit, beta $8 *$ & Psmb8 & 0.93 & Lmp-7;Lmp7 & NM 010724.1 & {$[14 \mid]$ reduced MHC class I } \\
\hline Solute carrier family 30 member 3 & $\mathrm{Slc} 30 \mathrm{a} 3$ & 0.93 & Znt3 & NM 011773 & [142] KO no phenotype \\
\hline DHHC-type $\mathrm{Zn}$-finger containing protein & 2400007G07Rik & 0.92 & & AK010296 & \\
\hline Chemokine (C-C motif) ligand 20 & $\mathrm{Ccl} 20$ & 0.92 & & NM_016960 & [143] $\mathrm{T}$ and $\mathrm{B}$ cell regulation \\
\hline Protease 28 subunit, beta $*$ & Psme2b & 0.92 & PA28b-p;Psme2-like & NM 011191.1 & [144] MHC Class I regulation \\
\hline DI30029J02Rik & DI30029J02Rik & 0.92 & & XM 150103 & \\
\hline F-box and leucine-rich repeat protein 14 & $\mathrm{FbxII4}$ & 0.92 & $\mathrm{Fb} \times|4|$ & NM 133940 & \\
\hline WD repeat \& FYVE domain containing I & Wdfyl & 0.92 & FENS-I;jrI;WDFI & NM 027057 & $\begin{array}{l}{[145] \text { Endosome and Golgi }} \\
\text { regulation }\end{array}$ \\
\hline $\begin{array}{l}\text { ADP-ribosylation factor-like } 6 \text { int. } \\
\text { protein } 2\end{array}$ & Arl6ip2 & 0.92 & Aip-2;AV334690 & NM 019717.1 & \\
\hline Protease 28 subunit, alpha & Psmel & 0.92 & PA28a & NM 011189.1 & $\begin{array}{l}\text { [146] Proteasome activator MHC } \\
\text { Class I }\end{array}$ \\
\hline TAFIO & Taflo & 0.92 & 30 kDa;Taf2h;TAFII30 & NM 020024.3 & [147] KO ICM phenotype \\
\hline Helicase with zinc finger domain & Helz & 0.91 & & NM 198298 & [148] Primitive streak expression \\
\hline $\begin{array}{l}\text { Transmembrane } 4 \text { superfamily member } \\
10\end{array}$ & Tm4sflo & 0.91 & BCMPI & NM $17577 \mid .2$ & \\
\hline II90004M23Rik & II90004M23Rik & 0.90 & & & \\
\hline Carbonic anhydrase 14 & Carl4 & 0.90 & & NM_0II797.I & [149] KO no phenotype \\
\hline Male enhanced antigen I & Meal & 0.90 & Mea-I & NM 010787.1 & [150] Testis development \\
\hline Delta-like 3, transcript variant I & DII3 & 0.90 & pu;pudgy & NM 007866.1 & [15I] primitive streak expression \\
\hline Ring finger protein 30 & Rnf30 & 0.90 & MURF;MURF-3 & NM 021447.1 & [152] Myogenic regulator \\
\hline
\end{tabular}

* More than one independent illumina probe for these genes were identified

the genes we identified as being epiblast-, early and late streak-specific and those recently identified using a similar EB differentiation system and Affymetrix arrays [10], and by other groups $[2,38]$. In addition, there are addition novel RIKEN cDNAs in these lists, which are likely to encode for interesting proteins worthy of further study (Additional files 5, 6).

Following the primitive streak wave of gene expression there was a dramatic activation of many genes (Figure 2A). Many of the most highly induced genes, such as globin genes, heme synthesis enzymes and haematopoietic transcription factors, are known to be expressed in the blood. qRT-PCR for globin genes confirmed $>10,000$ fold induction between days 3 and 8 with a steady decline thereafter (Figure 1). Other mesoderm and endoderm programs are also activated at this stage, so it is difficult to mine for these different outcomes.

\section{Enhanced cardiac gene expression and reduced erythropoiesis in serum-free ${ }^{B 4 L} E B$ culture}

Overall there were very strong similarities between ES cell differentiation in serum and serum-free cultures supplemented with $2 \mathrm{ng} / \mathrm{ml}$ BMP4. For example, all 29 of the primitive streak gene set, as defined from serum-containing cultures, were also expressed transiently and to a similar level in serum-free ${ }^{\mathrm{B} 4 \mathrm{~L}}$ media (Figure $3 \mathrm{~A}$ ). Genes differentially expressed at each EB time point (Day 1-16) were pooled and subjected to QT clustering to find sets differentially expressed between serum and serum-free ${ }^{\mathrm{B} 4 \mathrm{~L}}$ EB culture. Using a minimal cut-off of five genes per group, nine gene sets were identified; seven showed higher expression in serum and two showed higher expression in serum-free ${ }^{\mathrm{B} 4 \mathrm{~L}}$ (Table 3 and Figure 4).

The genes in set 9 were expressed more highly in serumfree $^{\mathrm{B} 4 \mathrm{~L}}$ media from day 6 , and genes in set 8 showed up- 
regulation at day 12 and 16 in the absence of serum (Figure 4). Both sets are comprised almost exclusively of cardiac-specific genes such as myosin heavy chain 7 (Myh7), myosin light chain 7 (Myl7), the cardiac isoform of $\alpha$ actin (Actc1), troponin (Tnnc2), tropomysin (Tpm2), the nicotinic cholinergic receptor (Chrng), and cardiac muscle fast twitch 1 specific ATPase (Atp2a1) (Table 3). Further interrogation of the array data revealed a cohort of cardiac transcription factors, including ISL1, MEF2C, Bop/Smyd1 and Hand2 [39], which were transiently up regulated 1.4 to 3.5 fold in serum-free ${ }^{\mathrm{B} 4 \mathrm{~L}}$ media compared to serum at day 6 (Signet Login_Bruce). Importantly, this elevated cardiac gene expression program correlated with increased numbers of spontaneously beating EBs in serum-free ${ }^{\mathrm{B} 4 \mathrm{~L}}$ media (data not shown). Enhanced expression ( 100 fold) of Actc1, Myl4 and Myl7 in serum-free ${ }^{\mathrm{B} 4 \mathrm{~L}}$ media compared with serum-containing media was confirmed by qRT-PCR (Figure 1). Taken together, this data strongly suggests cardiac muscle cell differentiation is either inhibited in serum or enhanced by the addition of BMP4 to serum-free culture.

The genes in set 2 were expressed in both serum and serum-free ${ }^{\mathrm{B} 4 \mathrm{~L}}$ conditions immediately following primitive streak formation, but expressed to higher levels and slightly earlier in serum (Table 3 and Figure 4). Many of these genes are globins (both embryonic and definitive) suggesting erythropoiesis is activated more robustly in the presence of serum (See Discussion). Alas2, a gene encoding the erythroid specific isoform of the first and rate limiting enzyme in the heme biosynthesis pathway, and the erythroid specific transcription factor, p45-NF-E2 are also in set 2 [40]. qRT-PCR for $\alpha$ - and $\beta$ h1-globin confirmed more rapid expression in serum versus $\mathrm{SF}^{\mathrm{B} 4 \mathrm{~L}}$ media (Figure 1), suggesting factors in addition to BMP4 enhance activation of the blood program from a similar primitive streak platform.

The genes in set 3 were expressed at a similar time in serum but expressed at very low levels or not at all in serum-free ${ }^{\mathrm{B} 4 \mathrm{~L}}$ media. Again, this set is highly enriched for erythroid specific genes such as alpha hemoglobin stabilising protein (Ahsp) [41], Glycophorin A, erythroid Kruppel-like factor (EKLF/Klf1) [42] and mitochondrial solute carrier protein (mitoferrin) [43] (Figure 4 and Table 3). Genes in sets 1 and 5 are activated more robustly at late time points in serum cultures. Most of these are specifically expressed in macrophages. Together, these results suggest delayed and less robust primitive haematopoiesis occurs in $\mathrm{SF}^{\mathrm{B} 4 \mathrm{~L}}$ culture compared with serum, an observation confirmed by less robust erythroid cell generation and 'redness' of the EBs from day 6-10 of differentiation (data not shown).

\section{Rapid changes in Kruppel-like factor gene expression upon ES cell differentiation}

Three Kruppel-like factor genes, Klf2, Klf4 and Klf5, were rapidly down regulated during the first few days of EB development (bold type in Table 1). All are members of the KLF family of transcription factors which are characterized by a similar C-terminal domain of three $\mathrm{C}_{2} \mathrm{H}_{2}$ zinc fingers which confers binding to CACC box elements in promoters and more distant regulatory elements $[44,45]$. $K l f 2$ and $K l f 4$ have N-terminal transcriptional action domains and act primarily as transcriptional activators, whereas Klf5 is best known as a transcriptional repressor [46]. Until recently, Klf2 and Klf4 were considered to have restricted expression patterns $[47,48]$ with gene knockout animals showing late developmental defects in vasculogenesis and skin differentiation, respectively $[49,50]$. Recently however, Klf4 expression was noted in ES cells $[19,51]$, and forced expression was shown to enhance Oct4 expression and promote self-renewal [51].

qRT-PCR confirmed the rapid down regulation of Klf2, $K l f 4$ and Klf5 in both serum and serum-free ${ }^{\mathrm{B} 4 \mathrm{~L}}$ differentiation conditions, although $K l f 5$ expression was down regulated more slowly (Figure 5A and 5B, and Table 4). Klf2, $K l f 4$ and Klf5 were all re-induced from day 3-5 of differentiation as mesoderm and endoderm developmental pathways are activated (Figure 5A and 5B). Sixteen of the 17 known KLFs were examined in detail throughout the entire differentiation time course (Table 4). Klf9 was also steadily down regulated ( $>10$ fold) between ES cells and day 5 EBs in serum and serum-free ${ }^{\mathrm{B} 4 \mathrm{~L}}$ media (Figure $5 \mathrm{~B}$ ). $K l f 3$, a well characterized transcriptional repressor [52] via its ability to recruit the co-repressor, CtBP [53], displayed an interesting biphasic expression pattern with initial rapid down regulation then re-induction from days 5-6 (Figure 5B). In contrast, Klf16 displayed little change in expression levels over the 16 days of EB maturation (Figure 5B).

Klf2 and Klf4 co-localize with OCT4 in the nuclei of ES cells (Figure 6A). Interestingly, all three proteins were found to preferentially reside in a nuclear sub-compartment (possibly nucleoli for transcription factories), suggesting possible co-involvement in a protein complex or network. Also, endogenous KLF2 was detected by specific CACC box DNA-binding activity in undifferentiated ES cells, which was lost upon EB differentiation (Figure 6B). In contrast, endogenous ES cell KLF4 DNA binding activity was not detected using the p18INK4c promoter CACC box sequence, although recombinant KLF4 was shown to bind to this probe (data not shown). SP1 and SP3 are ubiquitously expressed CACC-box binding proteins, which are dominant in ES cell nuclear extracts (Figure 6B). We hypothesize KLF2, KLF3, KLF4, KLF5 and KLF6 compete with SP1 family members for DNA binding to key cis 
Table 3: Genes differentially expressed during ES cell differentiation in serum versus serum-free defined media (BMP4 2 ng/ml)

\begin{tabular}{|c|c|c|c|c|c|}
\hline Set I - Chemokine ligands (Day 8) & Symbol & Synonyms & Genbank ID & BMP4 & Serum \\
\hline Hydroxyprostaglandin dehydrogenase 15 & Hpgd & & NM 008278.1 & 2.22 & 4.4 \\
\hline Src-like adaptor & Sla & Slap & NM 009192 & 1.29 & .90 \\
\hline Pleckstrin & Plek & & NM 019549.1 & 1.31 & 4.9 \\
\hline Triggering receptor expressed on myeloid cells-like I & Tremll & & $\underline{X M \quad 12864 \mid .3}$ & 1.67 & 12.6 \\
\hline Glycoprotein 5 (platelet) & Gp5 & GPV & NM 008148.2 & 1.52 & 8.9 \\
\hline 28I0484G07Rik & & & & 2.07 & 13.5 \\
\hline Chemokine (C-X-C motif) ligand 7 & Cxcl7 & b-TGI; CTAP3; LDGF; MDGF;NAP-2 & NM 023785.1 & 1.07 & 4.8 \\
\hline Angiotensin receptor I & Agtrl & ATI;ATIa;AT2RI & NM 177322.2 & 1.58 & 5.8 \\
\hline Arachidonate 12-lipoxygenase & Alox 12 & Alox I2p;P-I2LO & NM 007440.2 & 1.29 & 9.2 \\
\hline Chemokine (C-C motif) ligand 4 & $\mathrm{Ccl} 4$ & Act-2; MIP-IB & NM 013652 & 1.81 & 19.5 \\
\hline Chemokine (C-X-C motif) ligand 4 & $\mathrm{Cxcl} 4$ & Pf4;Scyb4 & NM 019932.1 & 3.85 & 29.0 \\
\hline ATPase, $\mathrm{Ca}^{2+}$ transporting, ubiquitous & Atp2a3 & Serca3 & NM 016745.2 & 1.30 & 6.1 \\
\hline Chemokine (C-C motif) ligand 3 & $\mathrm{Ccl} 3$ & Mipla;Scya3 & NM 011337.1 & 1.75 & 11.8 \\
\hline Set 2 - Globins (Day 6) & Symbol & Synonyms & Genbank ID & BMP4 & Serum \\
\hline$\beta$-major globin & Hbb-bl & & $\underline{\mathrm{AK} 002258}$ & 2.15 & 21.7 \\
\hline$\zeta$-globin & Hba-x & & NM 010405.2 & 4.30 & 128.3 \\
\hline$\varepsilon-y$ globin & Hbb-y & $\mathrm{E}-\mathrm{y}$ & NM 008221.2 & 1.80 & 38.1 \\
\hline Nuclear factor erythroid-2 (p45) & $\mathrm{Nfe} 2$ & P45NFE2 & NM 008685.2 & 1.32 & 10.4 \\
\hline$\alpha$-globin & Hba-al & Hbal & NM 008218.1 & 3.21 & 89.7 \\
\hline Band-3/anion exchanger I & Slc4al & Ael;CD233;Band 3 & NM 011403.1 & 1.19 & 26.2 \\
\hline Rik25I0042HI2 & & & AK011092 & 1.01 & 4.1 \\
\hline Aminolevulinic acid synthase 2 & Alas2 & Alas-2 & NM 009653.1 & 1.14 & 13.2 \\
\hline$\beta$ hl-globin & Hbb-bh I & betaHI & NM 008219.2 & 3.65 & 61.2 \\
\hline Set 3 - Blood (Day 8) & Symbol & Synonyms & Genbank ID & BMP4 & Serum \\
\hline Alpha hemoglobin stabilising protein & AHSP & AHSP;EDRF & NM 133245.I & 1.7 & 3.4 \\
\hline \multirow[t]{2}{*}{ Myeloperoxidase } & Mpo & & NM 010824 & I.I & 3.6 \\
\hline & Slc38a5 & SN2; JM24 & NM 172479.1 & 1.3 & 2.5 \\
\hline Glycophorin A & Gypa & CD235a;GPA & NM 010369.2 & 2.1 & 5.2 \\
\hline $\begin{array}{l}\text { Cbp/p300-interacting transactivator, with Glu/Asp- } \\
\text { rich carboxy-terminal domain, } 4\end{array}$ & Cited 4 & Mrg2 & NM 019563 & 1.3 & 2.5 \\
\hline Mitoferrin & Mscp & Slc25a37 & NM_030054.2 & 1.5 & 2.4 \\
\hline Kruppel-like factor I & KIfI & Eklf & NM 010635 & 1.8 & 3.6 \\
\hline Set 4 - Various (Day I6) & Symbol & Synonyms & Genbank ID & BMP4 & Serum \\
\hline FXYD domain-containing ion transport regulator 2 & Fxyd2 & AtplgI & NM 007503 & 1.38 & 6.7 \\
\hline Thioether S-methyltransferase & Temt & & NM 009349 & 0.97 & 6.0 \\
\hline $\begin{array}{l}\text { Mus musculus FXYD domain-containing ion transport } \\
\text { regulator } 2 \text {, transcript variant a }\end{array}$ & Fxyd2 & AtplgI & NM 052824.I & 1.16 & 5.7 \\
\hline Fibrinogen, alpha & Fga & Fib & NM 010196.1 & 2.06 & 11.8 \\
\hline Kininogen-I & Kngl & & NM 023125.2 & 6.25 & 37.3 \\
\hline Serum amyloid A 3 & Saa3 & Saa-3 & NM 011315 & 1.04 & 4.5 \\
\hline Deleted in azoospermia-like & Dazl & Dazla;Tpx-2;Tpx2 & NM 010021.2 & 0.91 & 3.8 \\
\hline Fibrinogen, alpha & Fga & Fib & NM 010196.1 & 2.57 & 14.3 \\
\hline Chitinase 3-like I & Chi3II & brp-39;Brp39;Gp39 & NM 007695.I & 1.75 & 7.3 \\
\hline Kininogen II & & & NM 201375.1 & 1.73 & 7.9 \\
\hline Set 5 - Macrophage (Day I6) & Symbol & Synonyms & Genbank ID & BMP4 & Serum \\
\hline Neutrophil cytosolic factor 2 & Ncf2 & Ncf-2; p67phox & NM 010877 & 2.05 & 3.56 \\
\hline Complement component Iq beta & $\mathrm{Clqb}$ & & NM 009777.I & 1.13 & 4.63 \\
\hline Matrix metalloproteinase 12 & Mmpl2 & Mmel & NM 008605.1 & 3.17 & 8.53 \\
\hline Complement component 3 & $\mathrm{C} 3$ & ASP;Plp & NM 009778.1 & 2.17 & 10.46 \\
\hline CD68 antigen & Cd68 & gpl I0;ScardI & NM 009853 & 1.84 & 5.58 \\
\hline
\end{tabular}


Table 3: Genes differentially expressed during ES cell differentiation in serum versus serum-free defined media (BMP4 2 ng/ml)

\begin{tabular}{|c|c|c|c|c|c|}
\hline Macrophage expressed gene I & Mpegl & & XM 129176 & 3.08 & 6.74 \\
\hline TYRO protein tyrosine kinase binding protein & Tyrobp & DAPI 2;KARAP;Ly83 & NM 011662.2 & 2.80 & 4.81 \\
\hline Myosin IF & Myolf & & NM 053214.1 & 1.64 & 3.33 \\
\hline Hematopoietic protein I & Hempl & & NM 153505.2 & 1.41 & 4.22 \\
\hline Glutathione S-transferase, alpha 3 & Gsta3 & Gst2-3 & NM 010356.2 & 1.73 & 8.67 \\
\hline Glycoprotein (transmembrane) nmb & Gpnmb & Dchil;ipd & NM 053110 & 1.55 & 6.63 \\
\hline Pleckstrin homology, Sec7 and coiled/coil domains 4 & Pscd4 & 25I0004M07Rik & NM 028195 & 1.54 & 3.83 \\
\hline B-cell leukaemia/lymphoma-2 related protein AIb & $\mathrm{Bcl} 2 \mathrm{alb}$ & Al-b & NM 007534 & 2.49 & 6.35 \\
\hline Complement component Iq, gamma & Clqg & $\mathrm{Clqc}$ & NM 007574.I & 1.26 & 5.27 \\
\hline Fc receptor, IgG, low affinity III & Fcgr3 & CDI6 & NM 010188.2 & 2.10 & 5.84 \\
\hline Lysozyme & Lyzs & Lys;Lzm;:Lzp & NM 017372.2 & 5.80 & 21.72 \\
\hline Chemokine (C-C motif) ligand 9 & Ccl9 & CCFI8;MRP-2; & NM 011338 & 2.26 & 3.85 \\
\hline B-cell leukemia 2 related protein AId & Bcl2ald & Al-d & NM 007536 & 2.51 & 4.49 \\
\hline EGF-like module containing, mucin-like, hormone & Emrl & F4/80; Ly7I;TM7LN3 & NM 010130.1 & 1.54 & 3.44 \\
\hline
\end{tabular}
receptor-like I

\begin{tabular}{|c|c|c|c|c|c|}
\hline Set 6 - Day 16 & Symobol & Synonyms & Genebank ID & BMP4 & Serum \\
\hline \multirow[t]{2}{*}{ Insulin-like growth factor I } & |gfl & C7300 I6P09Rik;lgf-I;lgf-I & NM 010512.2 & 1.6 & 4.8 \\
\hline & $\operatorname{Prss} 35$ & & NM 178738.1 & 4.7 & 5.9 \\
\hline $\begin{array}{l}\text { Protein tyrosine phosphatase, non-receptor type } \\
\text { substrate I }\end{array}$ & Ptpns I & CDI72a; SHP-I;SHPS-I; & $\underline{X M \quad 149 \mid 78.1}$ & 2.2 & 3.7 \\
\hline Apolipoprotein A-II & Apoa2 & Alp-2;Apoa-2;ApoA-II;Hdl-I & NM 013474.1 & 9.8 & 57.4 \\
\hline Spondin 2 , extracellular matrix protein & Spon2 & ;M-spondin;Mindin & NM 133903.2 & 2.0 & 12.0 \\
\hline Set 7 - Stem and late Day 16 & Symbol & Synonyms & Genbank ID & BMP4 & Serum \\
\hline Fbox 15 & Fbxol5 & & & 0.96 & 4.4 \\
\hline Aurora kinase $\mathrm{C}$ & Aurkc & AIEI;AIK3;StkI3 & NM 020572.I & 0.94 & 4.1 \\
\hline $220000 I I I 5 R i k$ & & & NM 183278.1 & 0.94 & 6.4 \\
\hline Hypothetical protein LOC236546 & & AF06706I & NM 199060.1 & 0.85 & 3.8 \\
\hline Eukaryotic translation initiation factor IA & LOCI95I50 & & XM 111306.1 & 0.80 & 9.3 \\
\hline Similar to Pro-Pol-dUTPase polyprotein; RNaseH & LOC386244 & & XM 359136.1 & 0.88 & 5.2 \\
\hline Similar to hypothetical protein FLJ35I05 & LOC245I09 & & $\underline{X M \quad 142517.3}$ & 0.89 & 3.7 \\
\hline Down regulated in renal cell carcinoma & Drrl & TU3A & AK044219 & 0.57 & 9.3 \\
\hline Set 8 - Cardiac Day 16 & Symbol & Synonyms & Genbank ID & BMP4 & Serum \\
\hline $\begin{array}{l}\text { ATPase, } \mathrm{Ca}++ \text { transporting, cardiac muscle, fast twitch } \\
\text { l }\end{array}$ & Atp2al & SERCAI & NM 007504.2 & 6.9 & 1.1 \\
\hline Cholinergic receptor, nicotinic, gamma & Chrng & Achr-3;Acrg & NM 009604.2 & 4.5 & 1.0 \\
\hline Myosin, light polypeptide I & & & BC059087.1 & 8.0 & 1.1 \\
\hline Alpha actin, skeletal muscle & Actal & Acta-2;Acts;Actsk-I & NM 009606.1 & 25.3 & 1.2 \\
\hline Tropomyosin 2 beta & Tpm2 & Tpm-2;Trop-2 & NM 009416.2 & 11.6 & 1.3 \\
\hline Cholinergic receptor, nicotinic, alpha & Chrnal & Achr-I;Acra & NM 007389.2 & 4.1 & 1.0 \\
\hline Troponin C2, fast & Tnnc2 & Tncs & NM 009394.2 & 5.7 & 0.9 \\
\hline Neurofilament 3 , medium & Nef3 & NF-M;NFI60;Nfm & NM 008691.1 & 4.5 & 1.1 \\
\hline Myosin heavy chain & Myh8 & & XM 354617 & 6.7 & 1.1 \\
\hline Cholinergic receptor, nicotinic, alpha I & Chrnal & Achr-I;Acra & NM 007389.2 & 5.4 & 1.1 \\
\hline Set 9 - Cardiac 2 Day 6 & Symbol & Synonyms & Genbank ID & BMP4 & Serum \\
\hline a-Actin, cardiac & Actcl & Actc-I & NM 009608.1 & 31.2 & 3.6 \\
\hline Somatostatin & Sst & Smst;SOM;SRIF;SS & NM 009215.1 & 10.8 & 2.2 \\
\hline Myosin, light polypeptide 7, regulatory & Myl7 & MLC2a;MYL2A;;RLC-A & NM 022879.1 & 14.3 & 4.7 \\
\hline Myosin, heavy polypeptide 7 , cardiac muscle, beta & Myh7 & Myhc-b;Myhcb & NM 080728.1 & 8.2 & 2.4 \\
\hline a-Actin, cardiac & Actcl & Actc-I & NM 009608.1 & 26.3 & 3.5 \\
\hline
\end{tabular}



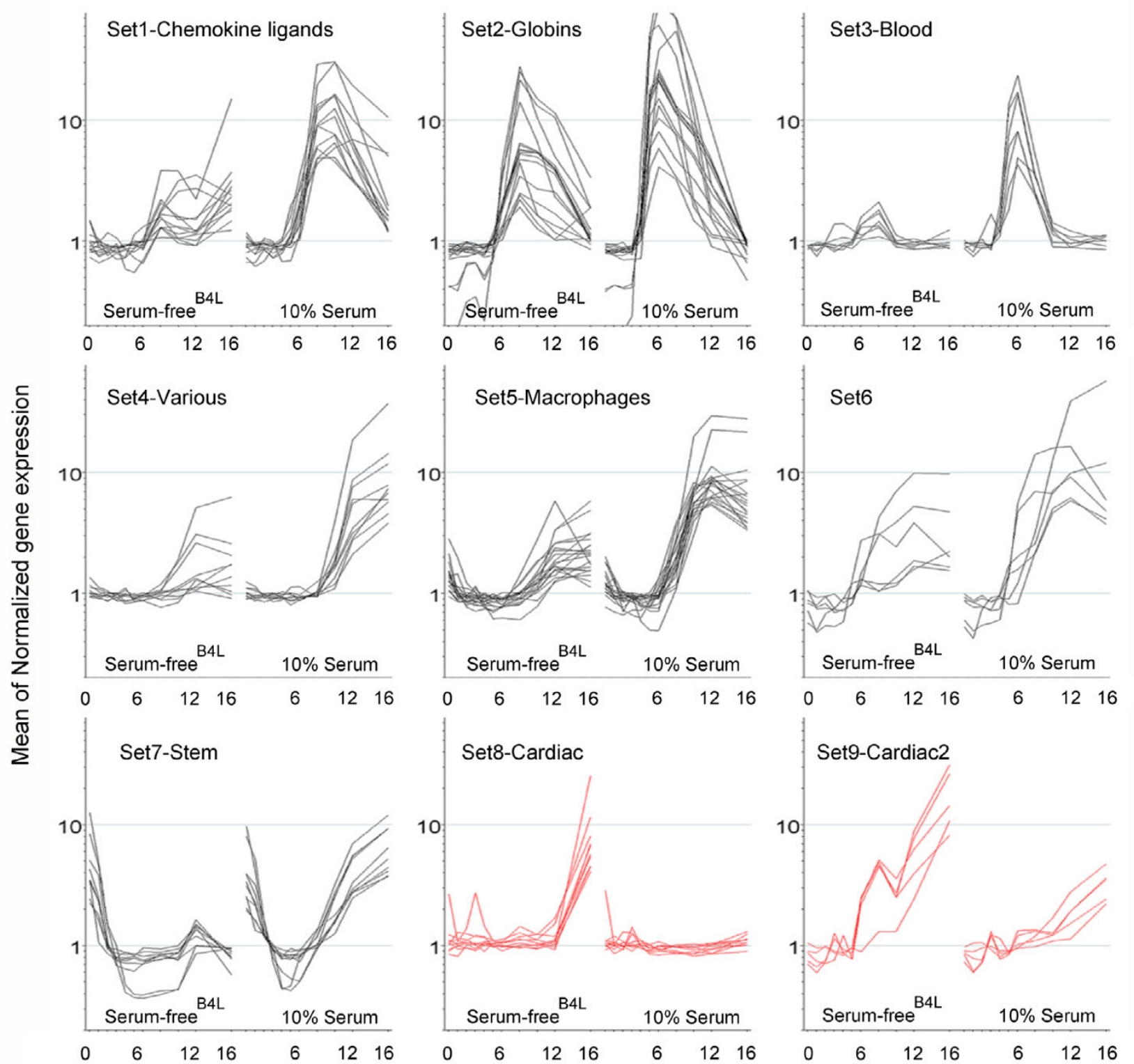

Days of Embryoid Body Growth

\section{Figure 4}

QT clustering revealed sets of genes differentially expressed between serum and serum-free ${ }^{\mathrm{B} 4 L} \mathrm{~EB}$ culture. QT clustering revealed nine sets of genes with similar dynamic expression profiles (Pearson Correlation coefficient of $>0.9$ ). In sets I-7, expression is higher in serum (black sets). In sets 8-9, expression is greater in serum-free ${ }^{\text {B4L }}$ EB culture (red sets). Some sets have been named based on the similarity of overall gene function during differentiation pathways (see Table 3). 
elements in various stem cell genes to regulate expression in positive and negative fashions (see Discussion).

\section{Enrichment of KLF-binding cis elements in the proximal promoters of stem cell specific genes}

To investigate whether Kruppel-like factors might directly regulate stem cell gene expression, and therefore play a role in the maintenance or loss of 'stemness', the presence of KLF transcription factor binding sites (TFBS) within the proximal promoters of all genes in Table 1 was determined. Although a position weighted matrix (PWM) for KLF4 binding site specificity has been published [54], this site does not resemble the CACC box sequences known to bind other KLFs. Since KLF4 has identical DNA-binding residues in each of its three $\mathrm{C}$-terminal $\mathrm{C}_{2} \mathrm{H}_{2}$ zinc fingers to other members of the Kruppel-like factor family [45], it should bind to similar sequences. Based on the crystal structure of the zinc fingers of Zif268 and SP1 bound to DNA $[55,56]$, and testing of specific binding of CACC box variants to recombinant KLF1, KLF3 and KLF17 $[45,52,57,58]$, a generic KLF TFBS has been proposed. Although a SELEX experiment for KLF1 binding has not been published, experiments from our group suggest a $\mathrm{C}$ at position 1, an $\mathrm{A}$ or $\mathrm{C}$ at position 3, an $\mathrm{A}$ at position 5, and an $\mathrm{A}, \mathrm{T}$ or $\mathrm{C}$ at position 9 of the $9 \mathrm{bp}$ consensus provides enhanced affinity for KLF1 binding. Taken together, these studies have enabled the development of a PWM (called here KLF-A) that should predict KLF4, KLF2 and other KLF TFBSs (see Methods and Additional file 7).

Clover [59] was used to determine if defined TFBSs were statistically over-represented in the stem cell lists. We searched for PWMs for KLF-A, KLF4 [54], octamer, extended octamer, nanog, and Oct-Sox binary sites as well as negative control sites (gata-1 and E-box) in sequences 2 $\mathrm{kb}$ upstream of the TSSs of stem cell genes (Table 1), versus $2 \mathrm{~kb}$ of sequences upstream of the entire murine transcriptome (See Additional file 7 for details of PWMs). There was significant over-representation of KLF-A TFBS within the first $2 \mathrm{~kb}$ of promoter sequences from the stem list gene list ( $\mathrm{p}$ value of $<0.01$ ) (Figure 7A), as well as over-representation of octamer sites and extended Oct4binding sites as defined from ChIP-PET data [60]. No statistically significant over-representation of KLF4 [54], NANOG, GATA1 or E-box TFBSs were identified. All genes in the rapidly down regulated gene list have at least one KLF-A type CACC site, or octamer or Oct4 [60] TFBS. A full list of the promoters with highlighted sites is available on request. Together, this data strongly suggests direct transcriptional regulation of many stem cell genes by KLFs.

The Zfp42/Rex1 gene promoter is presented as an example of output from the Clover program (Figure 7B). It contains five KLF-A, one octamer and three OCT4 TFBS. The two CACC box elements within the first 250 base pairs of the TSS represent classical extended KLF-binding sites $[42,61]$. These regions are the same as previously reported [62] although their functional importance has not been determined. Interestingly, two of the three KLF-A TFBS were evolutionarily conserved between the mouse and rat gene promoters (Figure 7C). Also, two further conserved CACC sites at -1.4 and $-1.5 \mathrm{~kb}$ were identified within 500 bp of extended evolutionary conservation (>70\% identity) (Figure 7C). This might act as a KLF dependent enhancer. Most of the stem cell genes in list 1 have conserved CACC box elements in their promoters [63-66]. In some cases these have been reported to bind the ubiquitous SP1, but our Clover analysis suggests they are also likely to bind KLFs (see Discussion).

\section{Discussion}

Expression profiling of murine ES cell differentiation was undertaken over a 16-day time course. We compared gene expression in methylcellulose cultures containing serum versus chemically defined media containing $\operatorname{LIF}(1 \mathrm{U} / \mathrm{ml})$ and low concentrations of BMP4 $(2 \mathrm{ng} / \mathrm{ml})$ [67]. The Illumina ${ }^{\circledR}$ Sentrix Mouse 6 bead array provided a sensitive and detailed platform for analysis of dynamic gene expression. Using various data mining approaches, lists of stem cellenriched genes and genes that are induced during the in vitro equivalent of epiblast and primitive streak stages of differentiation were generated. In combination with other ES cell profiling studies [7], our detailed expression data provides a useful resource for future reverse genetic approaches (i.e. siRNA knockdown) to study the function of these genes during ES cell differentiation and in vivo development. We also found a number of previously uncharacterized cDNAs (RIKEN clones) which could play important roles during development.

Importantly, the loss of pluripotency, measured by Oct 4 gene expression, was comparable between serum and serum-free ${ }^{\mathrm{B} 4 \mathrm{~L}} \mathrm{~EB}$ culture, following a predicted decrease over the first 6 days. Surprisingly, Oct4 gene expression gradually increased following day 6 , an observation independent of the cell lines used (data not shown). It remains undetermined if expansion of Oct4 positive ES cells persists as undifferentiated populations within our EB culture system. Previous studies have identified the development of Oct4 positive primordial germ cells (PGC) following 12 days of ES cell differentiation [68-70], suggesting the Oct4 profile may alternatively represent the expansion of non-ES cell populations. Although the expansion of some undifferentiated ES cells is possible, the array profile does not suggest global persistence or up-regulation of ES gene expression late in the EB program. Also, markers of mesoderm induction such as brachyury and Mixl, do not show persistent up-regulation following peak expression at day 4, suggesting EBs are unlikely to harbour cells which are 
Table 4: Kruppel-like factor gene expression during ES cell differentiation

\begin{tabular}{|c|c|c|c|c|c|c|c|c|}
\hline \multirow[t]{4}{*}{ Symbol } & \multirow[t]{4}{*}{ Synonyms } & \multirow[t]{4}{*}{ Genbank ID } & \multirow[t]{4}{*}{ Illumina ${ }^{\circledR}$ Probe ID } & \multicolumn{5}{|c|}{ Absolute Expression Level } \\
\hline & & & & \multirow{3}{*}{$\begin{array}{c}\text { ES Cell } \\
\text { Day } 0\end{array}$} & \multicolumn{4}{|c|}{ EB (Day) } \\
\hline & & & & & \multicolumn{2}{|c|}{ Serum-free } & \multicolumn{2}{|c|}{$10 \%$ Serum } \\
\hline & & & & & 3 & 6 & 3 & 6 \\
\hline KIfI & Eklf & NM 010635 & scl33570.4.I_25-S & 110 & 105 & 125 & 114 & 2138 \\
\hline $\mathrm{KIf}^{\mathrm{a}}$ & Lklf & NM 008452 & scl0I6598.3_26-S & 2275 & 269 & 157 & 272 & 248 \\
\hline \multirow[t]{3}{*}{ KIf3b } & Bklf;Tef-2 & $\begin{array}{l}\frac{\text { AK046659 }}{\text { NM } 008453} \\
\end{array}$ & ri|B430304G02| 3393-S & 112 & 92 & 80 & 102 & 99 \\
\hline & & & scl0016599.2_295-S & 894 & 406 & 733 & 374 & 881 \\
\hline & & & scl27779.8_253-S & 638 & 182 & 422 & 251 & 442 \\
\hline \multirow[t]{3}{*}{ KIf4a } & Gklf; Zie & NM 010637 & scl0016600.2_I55-S & 149 & 85 & 86 & 104 & 102 \\
\hline & & & scl00I6600.2_249-S & 575 & 89 & 109 & 112 & 127 \\
\hline & & & scl016600.7_29-S & 101 & 69 & 64 & 86 & 83 \\
\hline \multirow[t]{3}{*}{ KIf5a } & Bteb2;IKLF & NM 009769 & scl00I2224.2_233-S & 1981 & 699 & 232 & 699 & 274 \\
\hline & & & scl452I5.I.I_294-S & 79 & 91 & 83 & 112 & 105 \\
\hline & & & scl46026.3_338-S & 183 & 91 & 78 & 112 & 99 \\
\hline \multirow[t]{2}{*}{ KIf6 } & BCDI;CPBP;KIf6;Zf9 & NM 011803 & scl023849.4_8-S & 1107 & 1697 & 1540 & 1996 & 1457 \\
\hline & & & scl45096.3_II I5-S & 177 & 251 & 221 & 307 & 232 \\
\hline \multirow[t]{3}{*}{ KIf7 } & 9830I24P08Rik & $\begin{array}{l}\text { AK086122; } \\
\text { NM 033563 }\end{array}$ & ri|D930007COI| 248I-S & 319 & 243 & 207 & 270 & 227 \\
\hline & & & scl009369I.2_69-S & 334 & 281 & 202 & 345 & 231 \\
\hline & & & scll6685.5_486-S & 439 & 398 & 305 & 440 & 309 \\
\hline Klf8 & Klf8 & NM 173780 & scl024567I.I_6-S & 136 & 113 & 116 & 139 & 120 \\
\hline KIf9a & BTEB-I;KIf9 & NM 010638 & scl53274.2_I $28-S$ & 2035 & 910 & 205 & 1120 & 394 \\
\hline \multirow[t]{2}{*}{ KIfIO } & TiegI; Egra; Tieg & $\frac{\overline{N M ~ 013692}}{\text { AK043433 }}$ & scl47275.9_20-S & 84 & 83 & 70 & 96 & 92 \\
\hline & & & ri|A730095A08| 2144-S & 71 & 65 & 64 & 93 & 81 \\
\hline KIfII & Tieg3; Tieg2b; FKLF & NM 178357 & scl0194655.4_70-S & 71 & 68 & 67 & 86 & 78 \\
\hline \multirow[t]{5}{*}{ KIf I2 } & AP-2rep;BI30052C06Rik & NM 010636 & scl000297.I_3-S & 75 & 70 & 70 & 104 & 93 \\
\hline & & & scl0016597.I_0-S & 79 & 81 & 70 & 104 & 93 \\
\hline & & & scl016597.I_75-S & 92 & 102 & 86 & 122 & 121 \\
\hline & & & scl45206.9.I_30-S & 79 & 81 & 85 & 101 & 92 \\
\hline & & & scl452। 2.1.365_19-S & 62 & 61 & 56 & 75 & 73 \\
\hline KIfI3 & Bteb3;FKLF2; RFLAT-I & NM 021366 & scl3|250.6.4_2I-S & 291 & 284 & 245 & 332 & 308 \\
\hline \multirow[t]{3}{*}{ KIfI4 } & I I I0025J03Rik;Epfn;KIf|4 & NM 031183 & scl0083395.I_307-S & 109 & $|4|$ & 103 & 168 & 140 \\
\hline & & & scll3960.1.I_83-S & 167 & 193 & 166 & 237 & 183 \\
\hline & & & scll3961.I.I_105-S & 83 & 75 & 73 & 104 & 87 \\
\hline KIfI5 & 1810013109Rik;CKLF;KKLF & NM 023184 & scl2975I.3_94-S & 118 & 125 & 101 & 156 & 120 \\
\hline KIfI $6^{a}$ & BTEB4;DRRF & NM 078477 & scl37728.2_209-S & 355 & 181 & 177 & 249 & 167 \\
\hline
\end{tabular}

a. Enriched in undifferentiated ES cells

b. Biphasic expression pattern (See Figure 5)

delayed or arrested from entering the differentiation program.

We found significant differences in cardiac gene expression during EB differentiation in serum and serum-free ${ }^{\mathrm{B} 4 \mathrm{~L}}$ culture. Our current understanding of cardiac development provides possible insights into this observation. Briefly, in vivo studies have revealed BMPs secreted from the anterior lateral plate, and ill-defined signals from anterior primitive endoderm, are key inducers of cardiac development [71-73]. The administration of recombinant BMP2 or BMP4 to chick explant cultures induces cardiac differentiation in non-cardiogenic mesoderm [71] and Bmp2 knockout animals develop cardiac abnormalities [74]. Conversely, Wnts secreted by the neural tube are strong suppressors of cardiogenesis. Together, these opposing signals act to establish the borders of the heart field $[71,75]$. By mimicking the environment that establishes cardiogenesis in vivo, assays capable of directing cardiomyocyte production from ES cells have been established. BMPs can efficiently enhance the cardiac program when added to EB culture [76,77], whereas BMP inhibition drastically suppresses this outcome. In our hands cultures supplemented with BMP4 $(2 \mathrm{ng} / \mathrm{ml})$ sup- 
ported cardiomyocyte maturation (as determined by expression of cardiac specific genes) with greatest expression detected at Day 8-10. This correlated with increased numbers of spontaneously beating EBs, and the timing of initial spontaneous contractions during murine embryogenesis [78]. The cardiac program was significantly reduced in culture containing $10 \%$ serum, an observation supported by a number of other studies $[79,80]$. This suggests the constituents of serum are inhibitory to cardiomyocyte development. Although a detailed assessment of cardiomyocyte differentiation was not the focus of this analysis, the array output, qRT-PCR profiles and morphological observations described supports the usefulness of this assay in future investigations. In addition, the defined constituents of serum-free ${ }^{\mathrm{B} 4 \mathrm{~L}}$ media provides an excellent opportunity to identify additional recombinant factors required to further expand cardiac progenitor cell production from EBs.

In contrast, the hematopoietic program was more pronounced within EBs grown in 10\% serum than BMP4 alone (Figure 1 and 4). In particular, EKLF (Klf1) expression was significantly reduced in serum-free media supplemented with BMP4 $(2 \mathrm{ng} / \mathrm{ml})$ compared with serum (Figure 5A and Table 4). EKLF is essential for regulation of a large cohort of erythroid specific genes [81,82], many of which were identified in sets 2 and 3 (Figure 4). Thus, it is likely that reduced EKLF expression in $\mathrm{SF}^{\mathrm{B} 4 \mathrm{~L}}$ media directly results in inhibition of a cascade of erythroid gene expression. Previous work showed the addition of BMP (at $5 \mathrm{ng} /$ $\mathrm{ml}$ ) to serum-free ES cell culture induces EKLF expression and restores hematopoietic cell differentiation [83]. Although a weak hematopoietic program was observed in $\mathrm{SF}^{\mathrm{B} 4 \mathrm{~L}}$ culture, the concentration of BMP4 used was less than that used by Adelman et al. Thus, we suggest a robust cardiac (anterior-ventral mesoderm) gene expression program is induced by low conentrations of BMP4 (or other BMPs), whereas a robust blood gene expression program (posterior-ventral mesoderm) requires $>2 \mathrm{ng} / \mathrm{ml}$ of BMP4 or additional growth factors. Recently, mesoderm derived progenitor cell populations for hematopoietic and cardiac lineages were studied during EB development using ES cells in which GFP is targeted to the brachyury locus [80]. Within day 3.25 EBs, GFP+Flk1+ cells were shown to represent hematopoietic precursors, whereas GFP+Flk1- cells were significantly enriched for cardiac progenitor populations. It would be interesting to determine if the ratio of Flk1+/Flk1- within the brachyury positive population is altered between our two culture conditions.

A number of the Kruppel-like factor family of transcription factors were dynamically expressed in the first few days of ES cell differentiation. It was initially surprising to find highly enriched Klf2 and Klf4 expression in ES cells, since both are considered markers of terminally differen- tiated cell types such as skin [50], gut [84], vascular smooth muscle $[49,85]$ and lymphocytes [86]. However, recent evidence suggests KLFs may regulate stem cell function, since Klf4 is enriched in ES cells [19] and forced overexpression within these cells can maintain pluripotency in the absence of LIF [51]. Furthermore, Klf4 can bind the Lefty1 gene core promoter co-operatively with Oct4 and Sox2 [65]. Although Lefty 1 and 2 are best characterized as repressors of nodal, acting to regulate left-right patterning [87], our results and those of others, suggest a possible redundant role for lefty proteins during the maintenance of ES cell pluripotency [65]. Similarly to the Oct4 expression profile, many of the KLF family members also increased in expression late in the differentiation program. As mentioned, the KLFs are expressed in diverse tissues during development. It is therefore expected that the profiles obtained reflect the generation and early specification of mesoderm and endoderm cells following primitive streak gene activation at day 4 .

Based on the likely identical binding specificity of the KLF family, established transcriptional activation and repression roles of certain family members [44], and bioinformatic evidence of a high prevalence of KLF TFBSs in many stem cell genes, we propose KLF competition for occupancy of these CACC box elements might determine selfrenewal versus differentiation of ES cells. According to this model, high levels of KLF2 and KLF4 expression in undifferentiated ES cells would lead to occupancy of CACC box elements in promoters of stem cell genes such as Pou $5 \mathrm{fl} /$ Oct4, Nanog, Esrrb, Zfp42/Rex1, Lefty1 and Lefty2. Furthermore, the Klf2 and Klf4 genes themselves have CACC box elements in their proximal promoters (Figure 7A), suggesting a positive feedback loop within ES cells is likely. Interestingly, gene knockout and lentiviral shRNA gene knockdown of Klf2 or Klf4, does not lead to an obvious stem cell defect $[19,49,50,85]$, suggesting these two KLFs may have functionally redundant roles during the maintenance of pluripotency. Future analysis of KLF2/KLF4 double knockout ES lines or the knockdown of both proteins using RNAi technologies will be necessary to validate this hypothesis. Upon ES cell differentiation, down regulation of Klf2 and Klf4 was very rapid, whereas down regulation of Oct4 and Nanog was delayed for one to two days. We suggest loss of KLF2 and KLF4 binding to Pouf1/Oct4, Nanog, Esrrb and perhaps other stem cell promoters, could be directly responsible for their down regulation. Moreover, Klf5 was down regulated more slowly, and Klf3 was up-regulated in the first two days of differentiation, suggesting these KLFs may function primarily as transcriptional repressors at the Pouf1/Oct4, nanog, Zfp42 and Esrrb gene promoters. Once this differentiation driving transcription network is activated we suggest KLF3, KLF5 and KLF9 can accelerate loss of the stem cell state by directly repressing expression of the Klf2 and Klf4 genes them- 
A
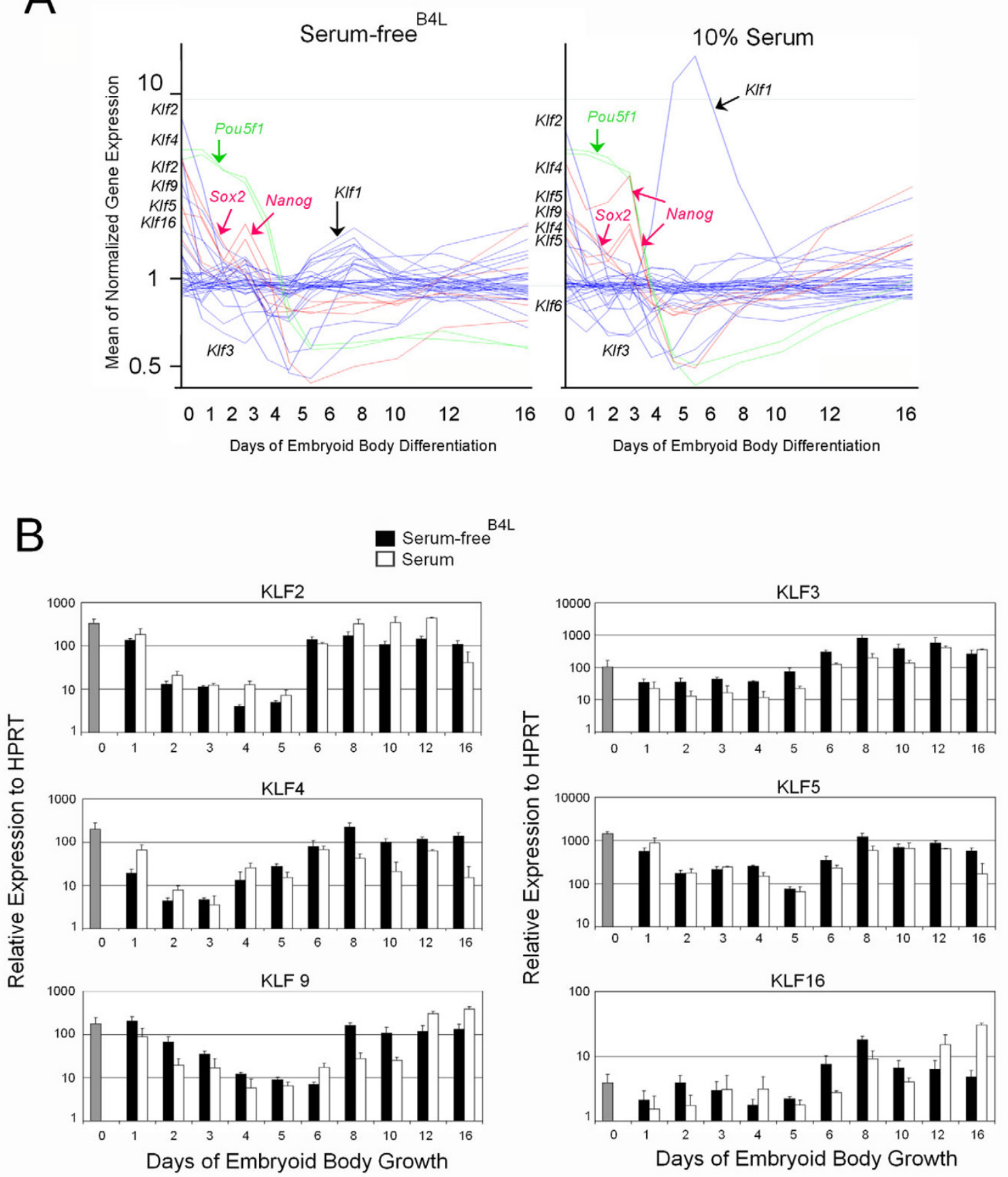

Figure 5

Kruppel like factors (KIfs) are dynamically expressed during the first few days of ES cell differentiation. (A) GeneSpring plot of normalized gene expression for all KLFs detected during ES cell differentiation in serum or serum-free ${ }^{\mathrm{B} 4 \mathrm{~L}}$ culture. Most of the genes are listed on the $y$-axis in order from their highest relative expression in ES cells. There is dramatic up regulation of KIfI (Eklf) only in serum following day 6 of differentiation. Plots representing Nanog (red), Sox2 (red) and Pou5fl (Oct4) (green) are shown for comparison. Pou5fl and Nanog gene expression persists at high levels for 2-3 days after KIf2, KIf4 and KIf5 are down regulated. (B) Validation of changes in gene expression of six members of the KLF family by quantitative real time RT-PCR. Scheme as described for Figure 2B. 
A
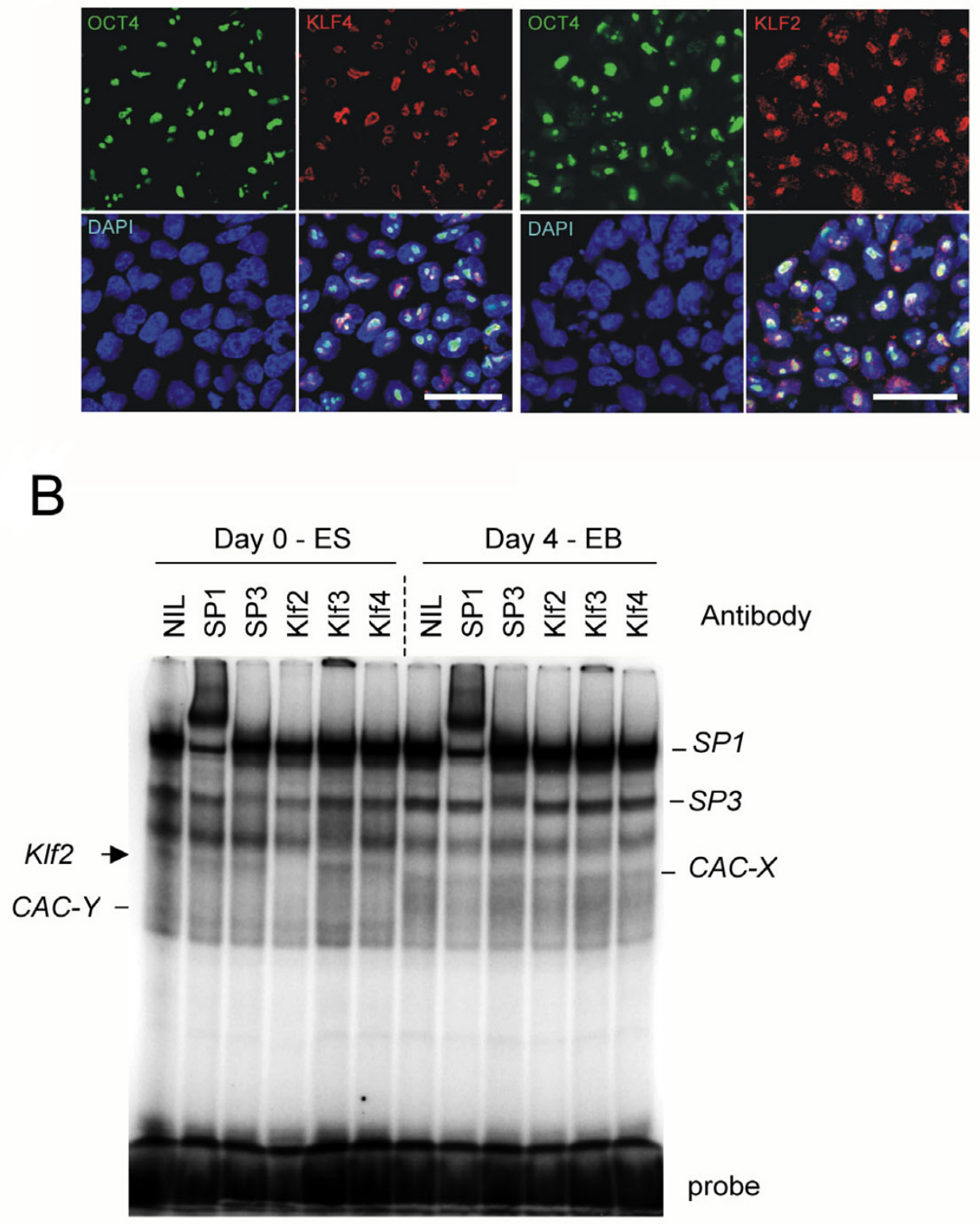

\section{Figure 6}

Kruppel like factor expression and DNA binding activity during ES cell differentiation. (A) Co-expression of Oct 4 with KLF2 or KLF4 in ES cells. Indirect immuno-fluorescence shows co-localization of KLF2 and KLF4 with Oct4 in sub-nuclear compartments (possibly nucleoli). Individual confocal images for OCT4, KLF2, KLF4, and DAPI are shown with the corresponding composite image. Scale bar $40 \mu \mathrm{m}$. (B) Electro-mobility gel shift assay showing changes in DNA binding activities at a conserved CACC box site in the pI8-INK4c gene promoter. Nuclear extracts were generated from ES cells or EBs differentiated for four days in serum. Super-shifts were performed with specific antisera for SPI, SP3, KLF2, KLF3, and KLF4 (See Methods). There is strong binding of endogenous SpI to the CACC element in ES cells and EB cells. KLF2 DNA-binding activity is present in ES cells as determined by a specific inhibition of binding of the indicated DNA complex with a KLF2 antibody. This activity is lost upon differentiation into EBs. The identity of the CACC box binding activity in EBs denoted CAC-X, and the binding activity in ES cells denoted CAC-Y, was not definitively identified using this panel of antibodies. 
A
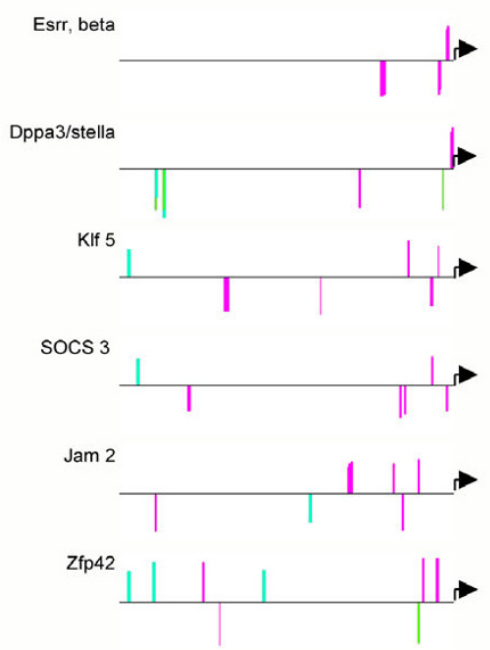

KIf 2

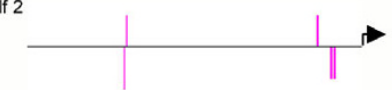

KIf 4
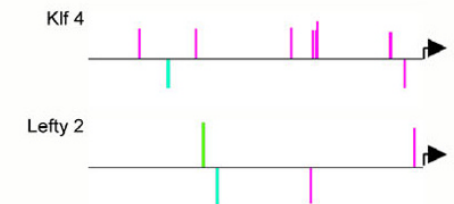

Lefty 1

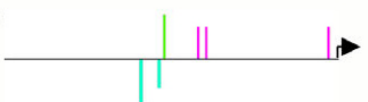

Latent TGF $\beta$ BP 4

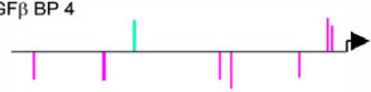

B

Zinc finger protein 42 (Rex1)

\begin{tabular}{lllll} 
sequence & position & \multicolumn{2}{l}{ strand motif } & score \\
tttgtttgctgttg & $46-60$ & + & Oct4-Loh & 7.17 \\
attctcatttaatg & $203-217$ & + & Oct4-Loh & 9.41 \\
cctcaccct & $498-506$ & + & KLF-A & 9.46 \\
agggtgtgg & $596-604$ & - & KLF-A & 10.4 \\
actcacatgcaaagg & $859-873$ & + & Oct4-Loh & 7.49 \\
atttgcat & $1786-1793$ & - & Octamer & 9.85 \\
ccccaccct & $1813-1821$ & + & KLF-A & 10.5 \\
ccccgccca & $1891-1899+$ & KLF-A & 9.29 \\
ccacaccca & $1897-1905+$ & KLF-A & 10.5
\end{tabular}

1 GCAGCTAATGGATAAAATTTCAGCAGTCCAAACATTTTGTTTTGTTTTGT 51 [TTGCTGTTGCTGCTPATATGCTTGCTTGCTGCGGGGTCTCATCCCTAAT 151 TACAGTCTCAGCCCACCCAAATGCTGGGTTTGCAAGCDAGAGACATGAAA 151 AACAGT 201 AAATTCTCATTTTAATG CACTTGAAATGACAGCCCGCTTCTCTTTTGTGG 301 CTATGGAAGCAAAGTTCCTATGTCCACAGATGAGTTTGTTCGTTTAGTGT 351 TCCTTTGGAGTGTGGGGAGGGACTTGGAAAGGAAAGCAAAATTGCAAT 401 GACAAAAATTAATAACAACAATGGACGTGTGAGGTGGAACAAGGACTCGA

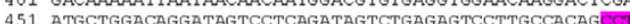
501 . 551 ETCCC.

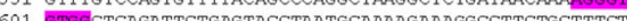
651 CCTTAACTACATAACTAAAAGGGAGGAAACTGAAACAGGGCCTC

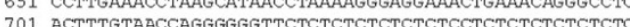
701 ACTTTGTAACCAGGGGGTTCTCTCTCTCTCTCTCCTCTCTCTCTCTCTC 11 А В51 АТАCACACACACACACACACACACACACACACACACACACACACTCACA 851 CCACACACACTCACATGCAAAGG CAGTCAGAGAACTTGTTGAGAATTTGC 901 CAATGTGTTTTGTTGTHTTTGTTTTTTGTTTTTTGTTTGTTTTGTTP 1001 CTCACTTTGTAGATCAGGCTGGCCTCGAACTCAGAAATCCGCCTGCCTCT 1051 GCCTCCCGAGTGGACCACGCCGGCTGCCAATGCATA 1051 (1) 1101 AATGAAG 1151 AGCCACAAACTCACTTCCGGGGATGACAGGAGGTTTATCCTACTTCCAT 1201 CAGAGGAATGGAGACACHCATAAATAG CAAAATTTCATCAGTCAAAA 1251 ATTTTTTTCGATCTCACAACTGAATTTTATTCAAAAGAAGAAAAAAAAAAA 1301 COAGATAGAAAGC 1351 CAGGTTAAATGTAAGAGGATCTAAATATTGATTTGGTTTTTGTCTTAAT 1401 GGTGCCCGGCGTATTTATACGAACCATTAAATTTCACTAGACOGTTTGTA 1451 GTCAGTGGTGAACGCTGCATGACCCACGCTCTCAAAGTGAGTTGTGTTGC 1501 TTTGCGGGAATCCAGCAGTCACATTAATGCTGGAAAAAGTTCAGGCAACT 1551 AGTGTACTTTGTAGCGGGGTCCGGGAGAGGCTGGGGTCTAGAGTGGCGA' 1601 GGGACGAAAGTGTAAAGAAAGTTTTCGGTGTGTGTGTGTGTGTGTGTGTC 1651 TGTGTGTGTGTGTGTGTGTAGGTAGGTAGGTAGAAACTGCATCCTCTGCI 1701 TGTGTAAATTCGGTTACAAGTCTGTAACAGAGGTACTGAGATGTGACTGA 1751 GTCTCAAGGCCAGGCGATCGGGATTCTGAAGAGGCATTTGCATAACTGAG 1801 CAAGAGTCTTTGCCCCACCCT TCCACGCCGACCCAAGACAAGGGGACAGC 1851 TCTGGGTGGGTCACCTGAAGGGCCAGGGGCCCGCCCACAT CCOCGCCCAC 1901 ACCCACCTTGAGCGCTTCTCATTGGGCATTCCAGCCTACCCAGCTCGGAC

C

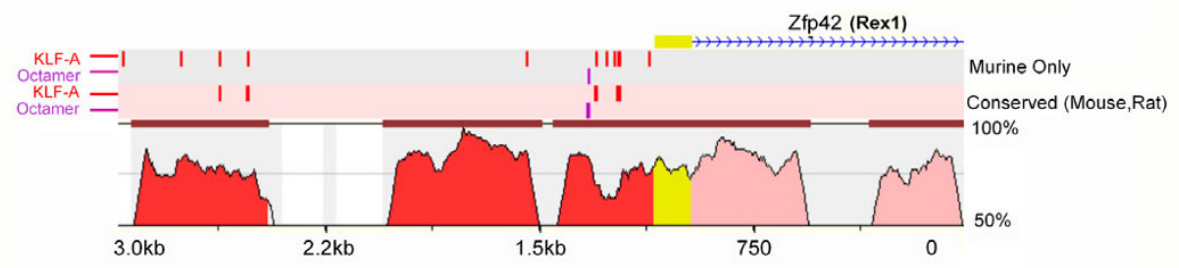

\section{Figure 7}

KLF and octamer binding sites are highly enriched in stem cell gene promoters. (A) A Clover analysis was used to identify over-represented transcription factor binding sites within the promoter sequences of all stem cell genes identified in Table I. Representative gene promoters are shown, indicating KLF-A binding sites (pink), octamer sites (ATGCWAAT) (green) and extended Oct4 binding sites (Oct4-Loh)(cyan) [60]. (B) Clover output for $2 \mathrm{~kb}$ of promoter sequence of murine Zfp42/Rexl. The positions and sequences corresponding to PWMs for KLF-A, octamer and Oct4 occupancy sites are indicated in the table and colour coded in the sequence. The positions are relative to the transcriptional start site. (C) ECR Browser output of conserved sequence identity between mouse and rat in the promoter and part of the first intron of the Zfp42 gene. The blue arrows indicate the direction of transcription. Yellow indicates the extent of the first (non-coding) exon, pink indicates regions of sequence conservation in the first intron and red indicates regions of sequence conservation in the $5^{\prime}$ upstream region. rVISTA was used to find all of the KLF-A and octamer sites in the murine gene (Murine only) and conserved sites between mouse and rat (Conserved mouse, rat). 
selves. Therefore, a combination of cross regulation of transcriptional outputs, and competition for occupancy of key stem cell promoters by KLF proteins with differing biochemical properties but identical DNA-binding capacities, may determine self-renewal versus differentiation outcomes. Again validation of this model requires functional analysis. It is important to note we have not proven occupancy of stem cell gene promoters by the KLFs in vivo. Chromatin immuno-precipitation (ChIP) experiments in ES cells and differentiated populations are essential to validate this model, however ChiP grade antibodies are not currently available.

This scenario is not necessarily limited to ES cell differentiation. A similar program may take place in many adult stem and progenitor cells populations. Certainly competition between Klf4 and Klf5 has been suggested to regulate cell growth [88], and Klf1 and Klf3 compete for binding and have opposing effects in blood cells [89]. Furthermore, an imbalance between occupancy of key stem cell or proliferation gene promoters by KLFs, with differing activating and repressing functions, could be responsible for the development or progression of many common forms of cancer. For example, loss of hetero-zygosity for Klf4 and Klf5 has been found in colon, stomach, breast, prostate and liver cancers $[90,91]$.

In addition to the proposed complex transcriptional interplay between KLFs and stem cell gene promoters, direct protein-protein interactions and protein networks involving KLFs are possible. We showed sub-nuclear localization of KLF2 and KLF4 with OCT4 in ES cells (Figure 6A), and KLF4 can co-operate with OCT4 and SOX2 to drive expression of the Lefty1 core promoter [65]. Also, very recent biochemical purification of NANOG-interacting proteins discovered KLF4 as part of a NANOG-OCT4 network in ES cells (Stuart Orkin, personal communication). This is also consistent with the ability of KLF4 to co-operate with OCT4, SOX2 and c-MYC to drive de-differentiation of fibroblasts into ES-like cells [24].

\section{Conclusion}

Defining the genetic regulation of ES cell self renewal and differentiation will be instrumental for the development of future cell based therapies. Using $47 \mathrm{~K}$ Illumina ${ }^{\circledR}$ Sentrix bead arrays, the differential expression of genes during 16 days of ES cell differentiation was determined. Hierarchical gene clustering and correlation statistical analyses lead to the identification of a small cohort of genes which define the stem cell state. Historically, ES cell differentiation is achieved in culture media containing 10-15\% FBS. A direct comparison between ES cell differentiation in serum and a serum-free media was undertaken. Surprisingly, global gene expression profiles were comparable between culture conditions, with the exception of meso- derm derived cardiac and haematopoietic transcripts. These results support the use of defined serum-free approaches for the directed differentiation of ES cell commitment. Expression of many KLF family members were enriched in ES cells and rapidly down regulated upon differentiation. KLF2 and KLF4 were co-localisation with OCT4 in ES cell nuclei and KLF transcription factor binding sites were over-represented within the promoters of the putative ES cell gene list $(\mathrm{p}<0.01)$. Taken together, this data strongly suggests KLF family members regulate the maintenance of ES cell pluripotency.

\section{Methods \\ ES cell culture, embryoid body formation and immunohistochemistry}

W9.5 ES cell differentiation was performed as described (Bruce et al., Differentiation, in press). For immuno-fluorescence, feeder depleted W9.5 ES cells were seeded onto sterile gelatin-coated glass cover slips in ES cell media, fixed in 4\% PFA for $10 \mathrm{~min}$ then washed in PBS. Cover slips were boiled in $10 \mathrm{mM}$ citric acid (pH 6.4) for $10 \mathrm{~min}$, washed in PBS and permeabilized in $0.18 \%$ triton X-100 in PBS for 10 mins. For OCT4/KLF4 detection, the cover slips were blocked in $1 \%$ BSA then incubated with rabbit polyclonal antibody raised against OCT4 (Abcam \#ab19857) and goat Anti-mouse KLF4 (R\&D Systems \#AF3158) overnight at $4{ }^{\circ} \mathrm{C}$, then incubated in goat antirabbit Alexa-488 (1:400) (Molecular Probes \#A11008) and donkey anti-goat Alexa-647 (1:400) for 1 hour. For co-detection of OCT4/KLF2, the Zenon Rabbit IgG labelling kit was used (Molecular Probes \#Z-25308). $1 \mu \mathrm{g}$ of KLF2 rabbit polyclonal antibody (Santa Cruz SC-28675) was labeled with Alexa647 Fab fragment following the manufacturer's instructions. Cover slips already stained for OCT4 (Alexa488) were incubated with labeled KLF2 for $1 \mathrm{hr}$ then washed and post-fixed in 4\% PFA to ensure strong signal detection. DAPI 1:5000 (Molecular Probes \#D3571) was used to detect nuclear localization. Cover slips were mounted on SuperFrost ${ }^{\circledast}$ Plus slides (MenzelGlaser) with VectaShield mounting media (Vector Laboratories H-1000). Confocal microscopy was performed on LSM 510 META Carl Zeiss microscope system.

\section{RNA extraction, cDNA synthesis and real-time RT-PCR data analysis}

Total RNA was made using TRIzol (Invitrogen), and cDNA was synthesized from $2 \mu \mathrm{g}$ of DNase1-treated total RNA using Superscript III (Invitrogen) and oligo-DT ${ }_{12-15}$ (Promega) according to the manufacturer's instructions. Quantitative RT-PCR (qRT-PCR) was carried out using the Applied Biosystems SYBR-green dye system and 7500 Real Time Cycler in 96-well plates. Cycling variables were as follows: $50^{\circ} \mathrm{C}$ for 2 minutes, $95^{\circ} \mathrm{C}$ for 10 minutes, then 40 cycles of 15 -second denaturation at $95^{\circ} \mathrm{C}$ and 1 minute at appropriate annealing temperatures, optimized 
for each set of primers based on dissociation curves (Additional file 8). Expression levels were normalized to HPRT as determined from the ratio of delta CT values. Mean of relative expression \pm SD was determined from three biological replicates. Sequencing of gel-purified amplicons was performed to ensure correct product amplification.

\section{Micro-array hybridization and analysis}

Expression profiling was performed using Sentrix Mouse6 Expression BeadChip arrays from Illumina ${ }^{\oplus}$. RNA was assessed for integrity using the Agilent Bioanalyzer 2100 and RNA integrity (RIN) scores above 9.5 were present in all samples. Amplification was performed with $500 \mathrm{ng}$ of total RNA using the Illumina TotalPrep RNA Amplification kit (Ambion) with a 12 hour in vitro transcription reaction period. The quantity and quality of biotin-UTP incorporated cRNA was also assessed on the Agilent Bioanalyzer 2100. Amplified cRNA (1500 ng per array) was hybridized to Mouse-6.v1 BeadChip arrays according to the manufacturer guidelines and detected with Fluorolink Streptavidin-Cy3 (Amersham Biosciences). Arrays were scanned using the Illumina BeadStation Scanner. The raw intensity values obtained for the scanned array images were compiled using the proprietary BeadStudio v1.5.1.3 software and imported into GeneSpring GX v7.3.1 (Agilent). A mouse Illumina probe set was defined in the GeneSpring Workgroup using the Illumina targetIDs as the unique identifiers and annotated according to array content files supplied by illumina ${ }^{\circledast}$. Data normalization was performed by first setting all measurements less than 0.01 to 0.01 , then applying per chip normalization to the $50^{\text {th }}$ percentile, and per gene normalization to the median.

From an interpretation which included the three FBS experiments, a non-parametric Welch ANOVA (where variances were not assumed equal) was performed on all 46,120 probes to find a subset of genes whose expression varied significantly throughout the differentiation time course. A Benjamini and Hochberg False Discovery Rate multiple testing correction was applied to reduce the number of false positives. This yielded a set of 7,967 probes that showed statistically significant $(\mathrm{p}<0.05)$ differences in expression by Welch t-test. This approach simplified running the data mining algorithms to find synexpression patterns by removing genes such as housekeeping genes which did not display differential expression, or genes which did not reach a threshold of expression at any time points.

Genome interpretations were generated in GeneSpring GXv7.3.1 (Agilent) in which the mean relative expression level for each gene was represented at each time point relative to the average of all time points. A number of statistical approaches were used to find syn-expression patterns. A Pearson correlation (between 0.9 and 1.0) was performed to find genes with similar expression profiles to Pouf1/Oct4, nanog, sox2, fgf5, wnt5 and brachyury. Hierarchical clustering was performed using the gene by gene and group by group 'tree' algorithm within the GeneSpring (Agilent) program. This compares each probe with every other in the lists to generate similarity statistics and a tree representation of similarity based on a Pearson correlation. Also, quality threshold (QT) clustering [92] was used to define distinct subsets of co-expressed genes. The entire data set for the experiments is available via GEO as well as via our instance of Genespring (contact corresponding author).

\section{Electro-mobility gel shift assays (EMSA)}

Nuclear extracts were made from undifferentiated ES cells and embryoid bodies grown for four days in 10\% serum. Electromobility gel shift assays (EMSA) were performed as previously described [61] using double stranded oligonucleotide probes corresponding to an extended CACC site in the p18INK4c promoter (sense strand 5'-gttgggeggggcgtgggcggggcc-3') (Tallack, et al., submitted). Supershifts were performed with specific antibodies raised against SP1 (Santa Cruz SC-059x), SP3 (Santa Cruz SC644x), KLF2 (Santa Cruz SC-28675), KLF3 [52] and KLF4 (Santa Cruz SC-12538x).

\section{Bioinformatic searches for CACC sites and other over represented elements in promoters of stem cell genes}

The data-mining tool Biomart (accessed via Ensembl release 36 of the mouse genome), was used to collate $2 \mathrm{~kb}$ of sequences upstream of the transcriptional start sites (TSSs) of all genes listed in Table 1. The Clover program, run via the MotifViz web interface [59], was used to search for over-representation of position weighted matrices (PWMs) for octamer [93], Oct4 [60], Oct-Sox [60], KLF4 [54], E-box, GATA-1 [94] and CACC (KLF-A) elements in these promoter sets. The PWMs are listed in Additional file 7. The ECR Browser [95] was used to determine phylogenetic conservation of cis elements between mouse, rat and human genomes.

\section{Abbreviations}

BSA, bovine serum albumin; EB, embryoid body; EMSA, electromobility gel shift assay; ES, embryonic stem; FBS, fetal bovine serum; KL, Fkruppel-like factor; LIF, leukemia inhibitory factor; $\mathrm{MEF}$, mouse embryonic fibroblasts; PFA, paraformaldehyde; PWM, position weighted matrix; TFBS, transcription factor binding sites.

\section{Competing interests}

The author(s) declares that there are no competing interests. 


\section{Authors' contributions}

SB established the EB differentiation assay, collected and purified RNA samples, designed and carried out the quantitative RT-PCR studies and drafted the manuscript. BG carried out the micro array protocol. LB Carried out experimentation of mesoderm specific gene expression. MG performed the array statistical analysis and annotation. SG participated in the design of the study and performed the statistical analysis. AP conceived the study, and participated in its design and coordination and helped to draft the manuscript. All authors read and approved the final manuscript.

\section{Additional material}

\section{Additional file 1}

Oct4 gene list. The data provided lists all genes expressed during 16 days of embryoid body differentiation with similarity to Oct4 (Pearson correlation $>0.9$ ).

Click here for file

[http://www.biomedcentral.com/content/supplementary/1471-

2164-8-365-S1.doc]

\section{Additional file 2}

Nanog gene list. The data provided lists all genes expressed during 16 days of embryoid body differentiation with similarity to Nanog (Pearson correlation >0.9).

Click here for file

[http://www.biomedcentral.com/content/supplementary/1471-

2164-8-365-S2.doc]

\section{Additional file 3}

Sox2 gene list. The data provided lists all genes expressed during 16 days of embryoid body differentiation with similarity to Sox2 (Pearson correlation $>0.9$ )

Click here for file

[http://www.biomedcentral.com/content/supplementary/1471-

2164-8-365-S3.doc]

\section{Additional file 4}

Sequence alignment of RIKEN clone 8430415E04RIK. The data provides an alignment of RIKEN clone 8430415 E04RIK using human, mouse, chick and zebrafish sequences.

Click here for file

[http://www.biomedcentral.com/content/supplementary/14712164-8-365-S4.doc]

\section{Additional file 5}

FGF5 gene list. The data provided lists all genes expressed during 16 days of embryoid body differentiation with similarity to FGF5 (Pearson correlation $>0.9$ ).

Click here for file

[http://www.biomedcentral.com/content/supplementary/14712164-8-365-S5.doc]

\section{Additional file 6}

Wnt5a gene list. The data provided lists all genes expressed during 16 days of embryoid body differentiation with similarity to Wnt5 (Pearson correlation >0.9).

Click here for file

[http://www.biomedcentral.com/content/supplementary/1471-

2164-8-365-S6.doc]

\section{Additional file 7}

Position Weighted Matrices. Provides published data on position weighted matrices for Oct, Sox, KLF-A, KLF4, Nanog, E-box, Gata-1 and their variants.

Click here for file

[http://www.biomedcentral.com/content/supplementary/1471-

2164-8-365-S7.doc]

\section{Additional file 8}

Oligonucleotide sequences used for qRT-PCR analysis. Lists the oligonucleotide sequences and cycling conditions used for the QRT-PCR analysis. Click here for file

[http://www.biomedcentral.com/content/supplementary/1471-

2164-8-365-S8.doc]

\section{Acknowledgements}

We acknowledge funding from Australian Stem Cell Centre (P02I), Wesley Research Institute (2006_04), and scholarship support from Kidney Health Australia.

\section{References}

I. Evans MJ, Kaufman MH: Establishment in culture of pluripotential cells from mouse embryos. Nature I98I, 292(58 I 9): I54- I56.

2. Keller G, Kennedy M, Papayannopoulou T, Wiles MV: Hematopoietic commitment during embryonic stem cell differentiation in culture. Mol Cell Biol I993, I 3(1):473-486.

3. Vittet D, Prandini MH, Berthier R, Schweitzer A, Martin-Sisteron H, Uzan G, Dejana E: Embryonic stem cells differentiate in vitro to endothelial cells through successive maturation steps. Blood 1996, 88(9):3424-343I.

4. Bain G, Kitchens D, Yao M, Huettner JE, Gottlieb DI: Embryonic stem cells express neuronal properties in vitro. Dev Biol 1995, 168(2):342-357.

5. Rohwedel J, Maltsev V, Bober E, Arnold HH, Hescheler J, Wobus AM: Muscle cell differentiation of embryonic stem cells reflects myogenesis in vivo: developmentally regulated expression of myogenic determination genes and functional expression of ionic currents. Dev Biol 1994, 164(1):87-101.

6. Ramalho-Santos M, Yoon S, Matsuzaki Y, Mulligan RC, Melton DA: "Stemness": transcriptional profiling of embryonic and adult stem cells. Science 2002, 298(5593):597-600.

7. Ivanova NB, Dimos JT, Schaniel C, Hackney JA, Moore KA, Lemischka IR: A stem cell molecular signature. Science 2002, 298(5593):60I-604.

8. Tanaka TS, Kunath T, Kimber WL, Jaradat SA, Stagg CA, Usuda M, Yokota T, Niwa H, Rossant J, Ko MS: Gene expression profiling of embryo-derived stem cells reveals candidate genes associated with pluripotency and lineage specificity. Genome Res 2002, I 2(I 2): 1921-1928.

9. Vogel G: Stem cells. 'Stemness' genes still elusive. Science 2003, 302(5644):37I.

10. Hirst CE, Ng ES, Azzola L, Voss AK, Thomas T, Stanley EG, Elefanty AG: Transcriptional profiling of mouse and human ES cells identifies SLAINI, a novel stem cell gene. Dev Biol 2006, 293(I):90-103. 
II. Bouhon IA, Kato H, Chandran S, Allen ND: Neural differentiation of mouse embryonic stem cells in chemically defined medium. Brain Res Bull 2005, 68(I-2):62-75.

12. Richards M, Tan SP, Tan JH, Chan WK, Bongso A: The transcriptome profile of human embryonic stem cells as defined by SAGE. Stem Cells 2004, 22(I):5I-64.

13. Kuhn K, Baker SC, Chudin E, Lieu MH, Oeser S, Bennett H, Rigault P, Barker D, McDaniel TK, Chee MS: A novel, high-performance random array platform for quantitative gene expression profiling. Genome Res 2004, I 4(I I):2347-2356

14. Okazaki Y, Furuno M, Kasukawa T, Adachi J, Bono H, Kondo S, Nikaido I, Osato N, Saito R, Suzuki H, Yamanaka I, Kiyosawa H, Yagi K, Tomaru Y, Hasegawa Y, Nogami A, Schonbach C, Gojobori T, Baldarelli R, Hill DP, Bult C, Hume DA, Quackenbush J, Schriml LM, Kanapin A, Matsuda H, Batalov S, Beisel KW, Blake JA, Bradt D, Brusic V, Chothia C, Corbani LE, Cousins S, Dalla E, Dragani TA, Fletcher CF, Forrest A, Frazer KS, Gaasterland T, Gariboldi M, Gissi C, Godzik A, Gough J, Grimmond S, Gustincich S, Hirokawa N, Jackson IJ, Jarvis ED, Kanai A, Kawaji H, Kawasawa Y, Kedzierski RM, King BL, Konagaya A, Kurochkin IV, Lee Y, Lenhard B, Lyons PA, Maglott DR, Maltais L, Marchionni L, McKenzie L, Miki H, Nagashima T, Numata K, Okido T, Pavan WJ, Pertea G, Pesole G, Petrovsky N, Pillai R, Pontius JU, Oi D, Ramachandran S, Ravasi T, Reed JC, Reed DJ, Reid J, Ring BZ, Ringwald M, Sandelin A, Schneider C, Semple CA, Setou M, Shimada K, Sultana R, Takenaka Y, Taylor MS, Teasdale RD, Tomita M, Verardo R, Wagner L, Wahlestedt C, Wang Y, Watanabe Y, Wells C, Wilming LG, Wynshaw-Boris A, Yanagisawa M, Yang I, Yang L, Yuan Z, Zavolan M, Zhu Y, Zimmer A, Carninci P, Hayatsu N, HirozaneKishikawa T, Konno H, Nakamura M, Sakazume N, Sato K, Shiraki T, Waki K, Kawai J, Aizawa K, Arakawa T, Fukuda S, Hara A, Hashizume W, Imotani K, Ishii Y, Itoh M, Kagawa I, Miyazaki A, Sakai K, Sasaki D, Shibata K, Shinagawa A, Yasunishi A, Yoshino M, Waterston R, Lander ES, Rogers J, Birney E, Hayashizaki Y: Analysis of the mouse transcriptome based on functional annotation of 60,770 fulllength cDNAs. Nature 2002, 420(69/5):563-573.

15. Verdugo RA, Medrano JF: Comparison of gene coverage of mouse oligonucleotide microarray platforms. BMC Genomics 2006, 7:58

16. Perkins AC: Enrichment of blood from embryonic stem cells in vitro. Reprod Fertil Dev 1998, 10(7-8):563-572.

17. Wiles MV, Johansson BM: Embryonic stem cell development in a chemically defined medium. Exp Cell Res 1999 247(I):24I-248.

18. Bhattacharya B, Miura T, Brandenberger R, Mejido J, Luo Y, Yang AX, Joshi BH, Ginis I, Thies RS, Amit M, Lyons I, Condie BG, ItskovitzEldor J, Rao MS, Puri RK: Gene expression in human embryonic stem cell lines: unique molecular signature. Blood 2004, I 03(8):2956-2964.

19. Ivanova N, Dobrin R, Lu R, Kotenko I, Levorse J, DeCoste C, Schafer $X$, Lun Y, Lemischka IR: Dissecting self-renewal in stem cells with RNA interference. Nature 2006, 442(7/ 02):533-538.

20. Nilsson SK, Johnston HM, Whitty GA, Williams B, Webb RJ, Denhardt DT, Bertoncello I, Bendall LJ, Simmons PJ, Haylock DN: Osteopontin, a key component of the hematopoietic stem cell niche and regulator of primitive hematopoietic progenitor cells. Blood 2005, 106(4): 1232-1239.

2I. Botquin V, Hess H, Fuhrmann G, Anastassiadis C, Gross MK, Vriend G, Scholer HR: New POU dimer configuration mediates antagonistic control of an osteopontin preimplantation enhancer by Oct-4 and Sox-2. Genes Dev 1998, I 2(I3):2073-2090.

22. Jin J, Cardozo T, Lovering RC, Elledge SJ, Pagano M, Harper JW: Systematic analysis and nomenclature of mammalian F-box proteins. Genes Dev 2004, I 8(2I):2573-2580.

23. Tokuzawa $Y$, Kaiho E, Maruyama M, Takahashi K, Mitsui K, Maeda M, Niwa $H$, Yamanaka S: FbxI5 is a novel target of Oct3/4 but is dispensable for embryonic stem cell self-renewal and mouse development. Mol Cell Biol 2003, 23(8):2699-2708.

24. Takahashi K, Yamanaka S: Induction of pluripotent stem cells from mouse embryonic and adult fibroblast cultures by defined factors. Cell 2006, I 26(4):663-676.

25. Nichols J, Zevnik B, Anastassiadis K, Niwa H, Klewe-Nebenius D, Chambers I, Scholer H, Smith A: Formation of pluripotent stem cells in the mammalian embryo depends on the POU transcription factor Oct4. Cell 1998, 95(3):379-391.
26. Avilion AA, Nicolis SK, Pevny LH, Perez L, Vivian N, Lovell-Badge R: Multipotent cell lineages in early mouse development depend on SOX2 function. Genes Dev 2003, I7(I): I 26-I 140.

27. Chambers I, Colby D, Robertson M, Nichols J, Lee S, Tweedie S, Smith A: Functional expression cloning of Nanog, a pluripotency sustaining factor in embryonic stem cells. Cell 2003 , I I3(5):643-655

28. Rosner MH, Vigano MA, Ozato K, Timmons PM, Poirier F, Rigby PW, Staudt LM: A POU-domain transcription factor in early stem cells and germ cells of the mammalian embryo. Nature 1990 , 345(6277):686-692.

29. Wilkinson DG, Bhatt S, Herrmann BG: Expression pattern of the mouse $T$ gene and its role in mesoderm formation. Nature 1990, 343(6259):657-659.

30. Hart AH, Hartley L, Sourris K, Stadler ES, Li R, Stanley EG, Tam PP, Elefanty AG, Robb $L$ : MixII is required for axial mesendoderm morphogenesis and patterning in the murine embryo. Development 2002, I29( I 5):3597-3608.

31. Tsang TE, Shawlot W, Kinder SJ, Kobayashi A, Kwan KM, Schughart $K$, Kania A, Jessell TM, Behringer RR, Tam PP: Lim I activity is required for intermediate mesoderm differentiation in the mouse embryo. Dev Biol 2000, 223(I):77-90.

32. Treichel D, Becker MB, Gruss P. The novel transcription factor gene $\mathrm{Sp} 5$ exhibits a dynamic and highly restricted expression pattern during mouse embryogenesis. Mech Dev 200I, I0 I I2): $175-179$.

33. Ciruna BG, Rossant J: Expression of the T-box gene Eomesodermin during early mouse development. Mech $\operatorname{Dev} 1999$ 8I(I-2): 199-203.

34. Peifer $M$, Berg $S$, Reynolds $A B$ : A repeating amino acid motif shared by proteins with diverse cellular roles. Cell 1994, 76(5):789-79|.

35. Haub O, Goldfarb M: Expression of the fibroblast growth factor-5 gene in the mouse embryo. Development |991, I I 2(2):397-406.

36. Gofflot F, Hall M, Morriss-Kay GM: Genetic patterning of the developing mouse tail at the time of posterior neuropore closure. Dev Dyn 1997, 21 0(4):43 I-445.

37. Okano M, Bell DW, Haber DA, Li E: DNA methyltransferases Dnmt3a and Dnmt3b are essential for de novo methylation and mammalian development. Cell 1999, 99(3):247-257.

38. Chen Y, Amende I, Hampton TG, Yang Y, Ke Q, Min JY, Xiao YF, Morgan JP: Vascular endothelial growth factor promotes cardiomyocyte differentiation of embryonic stem cells. Am J Physiol Heart Circ Physiol 2006, 29 I(4):HI653-8.

39. Black BL: Transcriptional pathways in second heart field development. Semin Cell Dev Biol 2007, 18(I):67-76.

40. Andrews NC, Kotkow KJ, Ney PA, Erdjument-Bromage H, Tempst P, Orkin $\mathrm{SH}$ : The ubiquitous subunit of erythroid transcription factor NF-E2 is a small basic-leucine zipper protein related to the v-maf oncogene. Proc Natl Acad Sci U S A 1993, 90(24): I | 488-I | 492 .

4I. Kihm AJ, Kong Y, Hong W, Russell JE, Rouda S, Adachi K, Simon MC, Blobel GA, Weiss MJ: An abundant erythroid protein that stabilizes free alpha-haemoglobin. Nature 2002, 4I7(6890):758-763.

42. Miller IJ, Bieker J]: A novel, erythroid cell-specific murine transcription factor that binds to the CACCC element and is related to the Kruppel family of nuclear proteins. Mol Cell Biol 1993, 13(5):2776-2786

43. Shaw GC, Cope J], Li L, Corson K, Hersey C, Ackermann GE, Gwynn B, Lambert AJ, Wingert RA, Traver D, Trede NS, Barut BA, Zhou Y, Minet E, Donovan A, Brownlie A, Balzan R, Weiss MJ, Peters LL, Kaplan J, Zon LI, Paw BH: Mitoferrin is essential for erythroid iron assimilation. Nature 2006, 440(7080):96-100.

44. Philipsen S, Suske G: $\mathbf{A}$ tale of three fingers: the family of mammalian Sp/XKLF transcription factors. Nucleic Acids Res 1999 , 27( 15):299I-3000

45. Perkins A: Erythroid Kruppel like factor: from fishing expedition to gourmet meal. Int \& Biochem Cell Biol 1999, 3I(10): II75-II 192.

46. Suske G, Bruford E, Philipsen S: Mammalian SP/KLF transcription factors: bring in the family. Genomics 2005, 85(5):55 I-556.

47. Anderson KP, Kern CB, Crable SC, Lingrel JB: Isolation of a gene encoding a functional zinc finger protein homologous to 
erythroid Kruppel-like factor: identification of a new multigene family. Mol Cell Biol I995, I 5(I I):5957-5965

48. Shields JM, Christy RJ, Yang VW: Identification and characterization of a gene encoding a gut-enriched Kruppel-like factor expressed during growth arrest. J Biol Chem 1996, 27I(33):20009-200 I7

49. Kuo CT, Veselits ML, Barton KP, Lu MM, Clendenin C, Leiden JM: The LKLF transcription factor is required for normal tunica media formation and blood vessel stabilization during murine embryogenesis. Genes Dev 1997, I I (22):2996-3006.

50. Segre JA, Bauer C, Fuchs E: KIf4 is a transcription factor required for establishing the barrier function of the skin. Nat Genet 1999, 22(4):356-360

5I. Li Y, McClintick J, Zhong L, Edenberg HJ, Yoder MC, Chan RJ: Murine embryonic stem cell differentiation is promoted by SOCS-3 and inhibited by the zinc finger transcription factor KIf4. Blood 2005, 105(2):635-637.

52. Crossley M, Whitelaw E, Perkins A, Williams G, Fujiwara Y, Orkin SH: Isolation and characterization of the CDNA encoding BKLF/ TEF-2, a major CACCC-box-binding protein in erythroid cells and selected other cells. Mol Cell Biol 1996, 16(4): 1695-1705

53. Turner J, Crossley M: Cloning and characterization of $\mathbf{m C t B P 2}$ a co-repressor that associates with basic Kruppel-like factor and other mammalian transcriptional regulators. Embo | 1998, I7(I7):5129-5|40.

54. Shields JM, Yang VW: Identification of the DNA sequence that interacts with the gut-enriched Kruppel-like factor. Nucleic Acids Res 1998, 26(3):796-802.

55. Pavletich NP, Pabo CO: Zinc finger-DNA recognition: crystal structure of a Zif268-DNA complex at 2.1 A. Science 1991, 252(5007):809-817.

56. Oka S, Shiraishi $Y$, Yoshida T, Ohkubo T, Sugiura $Y$, Kobayashi $Y$ : NMR structure of transcription factor SpI DNA binding domain. Biochemistry 2004, 43(5I): 16027-16035

57. Feng WC, Southwood CM, Bieker JJ: Analyses of beta-thalassemia mutant DNA interactions with erythroid Kruppellike factor (EKLF), an erythroid cell-specific transcription factor. I Biol Chem 1994, 269(2): | 493-1500.

58. van Vliet J, Crofts LA, Quinlan KG, Czolij R, Perkins AC, Crossley M: Human KLFI7 is a new member of the Sp/KLF family of transcription factors. Genomics 2006, 87(4):474-482.

59. Fu Y, Frith MC, Haverty PM, Weng Z: MotifViz: an analysis and visualization tool for motif discovery. Nucleic Acids Res 2004 32(Web Server issue):W420-3.

60. Loh YH, Wu Q, Chew JL, Vega VB, Zhang W, Chen X, Bourque G, George J, Leong B, Liu J, Wong KY, Sung KW, Lee CW, Zhao XD, Chiu KP, Lipovich L, Kuznetsov VA, Robson P, Stanton LW, Wei CL Ruan Y, Lim B, Ng HH: The Oct4 and Nanog transcription network regulates pluripotency in mouse embryonic stem cells. Nat Genet 2006, 38(4):43I-440.

61. Perkins AC, Sharpe AH, Orkin SH: Lethal beta-thalassaemia in mice lacking the erythroid CACCC- transcription factor EKLF. Nature 1995, 375(6529):318-322.

62. Ben-Shushan E, Thompson JR, Gudas LJ, Bergman Y: Rex-I, a gene encoding a transcription factor expressed in the early embryo, is regulated via Oct-3/4 and Oct-6 binding to an octamer site and a novel protein, Rox- I, binding to an adjacent site. Mol Cell Biol I998, I8(4):|866-I878.

63. Wu DY, Yao Z: Functional analysis of two Spl/Sp3 binding sites in murine Nanog gene promoter. Cell Res 2006, 16(3):319-322.

64. Pesce M, Marin Gomez M, Philipsen S, Scholer HR: Binding of SpI and $\mathrm{Sp} 3$ transcription factors to the Oct-4 gene promoter. Cell Mol Biol (Noisy-le-grand) 1999, 45(5):709-7I6.

65. Nakatake Y, Fukui N, Iwamatsu Y, Masui S, Takahashi K, Yagi R, Yag K, Miyazaki J, Matoba R, Ko MS, Niwa H: KIf4 cooperates with Oct3/4 and Sox2 to activate the Leftyl core promoter in embryonic stem cells. Mol Cell Biol 2006, 26(20):7772-7782.

66. Hosler BA, Rogers MB, Kozak CA, Gudas LJ: An octamer motif contributes to the expression of the retinoic acid-regulated zinc finger gene Rex-I (Zfp-42) in F9 teratocarcinoma cells. Mol Cell Biol 1993, I3(5):2919-2928.

67. Johansson BM, Wiles MV: Evidence for involvement of activin A and bone morphogenetic protein 4 in mammalian meso- derm and hematopoietic development. Mol Cell Biol 1995, I5(I):|4|-|5|.

68. Hubner K, Fuhrmann G, Christenson LK, Kehler J, Reinbold R, De La Fuente R, Wood J, Strauss JF 3rd, Boiani M, Scholer HR: Derivation of oocytes from mouse embryonic stem cells. Science 2003, 300(5623): $125|-| 256$

69. Clark AT, Bodnar MS, Fox M, Rodriquez RT, Abeyta MJ, Firpo MT, Pera RA: Spontaneous differentiation of germ cells from human embryonic stem cells in vitro. Hum Mol Genet 2004, I3(7):727-739.

70. Lacham-Kaplan $\mathrm{O}$, Chy $\mathrm{H}$, Trounson A: Testicular cell conditioned medium supports differentiation of embryonic stem cells into ovarian structures containing oocytes. Stem Cells 2006, 24(2):266-273

7I. Schultheiss TM, Burch JB, Lassar AB: A role for bone morphogenetic proteins in the induction of cardiac myogenesis. Genes Dev 1997, I I(4):45I-462.

72. Schultheiss TM, Xydas S, Lassar AB: Induction of avian cardiac myogenesis by anterior endoderm. Development 1995, | 2 I (12):4203-42 I 4.

73. Sugi Y, Lough J: Anterior endoderm is a specific effector of terminal cardiac myocyte differentiation of cells from the embryonic heart forming region. Dev Dyn 1994, 200(2): $155-162$.

74. Zhang $\mathrm{H}$, Bradley $A$ : Mice deficient for $\mathbf{B M P 2}$ are nonviable and have defects in amnion/chorion and cardiac development. Development 1996, I 22( I 0):2977-2986.

75. Tzahor $E$, Lassar $A B$ : Wnt signals from the neural tube block ectopic cardiogenesis. Genes Dev 200I, I5(3):255-260.

76. Kawai T, Takahashi T, Esaki M, Ushikoshi H, Nagano S, Fujiwara H, Kosai K: Efficient cardiomyogenic differentiation of embryonic stem cell by fibroblast growth factor 2 and bone morphogenetic protein 2. Circ J 2004, 68(7):691-702.

77. Hosseinkhani $M$, Hosseinkhani $H$, Khademhosseini A, Bolland $F$ Kobayashi H, Prat Gonzalez S: Bone morphogenetic protein-4 enhances cardiomyocyte differentiation of cynomolgus monkey ES cells in Knockout Serum Replacement medium. Stem Cells 2006

78. Nishii K, Shibata $Y$ : Mode and determination of the initial contraction stage in the mouse embryo heart. Anat Embryol (Berl) 2006, 211 I(2):95-100.

79. Zandstra PW, Bauwens C, Yin T, Liu Q, Schiller H, Zweigerdt R, Pasumarthi KB, Field LJ: Scalable production of embryonic stem cell-derived cardiomyocytes. Tissue Eng 2003, 9(4):767-778.

80. Kouskoff V, Lacaud G, Schwantz S, Fehling HJ, Keller G: Sequential development of hematopoietic and cardiac mesoderm during embryonic stem cell differentiation. Proc Natl Acad Sci U S A 2005, 102(37): |3|70-13|75.

8I. Drissen R, von Lindern M, Kolbus A, Driegen S, Steinlein P, Beug H, Grosveld F, Philipsen S: The erythroid phenotype of EKLF-null mice: defects in hemoglobin metabolism and membrane stability. Mol Cell Biol 2005, 25( I 2):5205-52 I4.

82. Hodge D, Coghill E, Keys J, Maguire T, Hartmann B, McDowall A Weiss M, Grimmond S, Perkins A: A global role for EKLF in definitive and primitive erythropoiesis. Blood 2006 , 107(8):3359-3370.

83. Adelman CA, Chattopadhyay S, Bieker J]: The BMP/BMPR/Smad pathway directs expression of the erythroid-specific EKLF and GATAI transcription factors during embryoid body differentiation in serum-free media. Development 2002, I 29(2):539-549.

84. Shie JL, Chen ZY, O'Brien MJ, Pestell RG, Lee ME, Tseng CC: Role of gut-enriched Kruppel-like factor in colonic cell growth and differentiation. Am J Physiol Gastrointest Liver Physiol 2000, 279(4):G806-14.

85. Wani MA, Means RT Jr., Lingrel JB: Loss of LKLF function results in embryonic lethality in mice. Transgenic Res 1998, 7(4):229-238.

86. Kuo CT, Veselits ML, Leiden JM: LKLF: A transcriptional regulator of single-positive $T$ cell quiescence and survival. Science 1997, 277(5334): 1986-1990.

87. Meno C, Shimono A, Saijoh Y, Yashiro K, Mochida K, Ohishi S, Noji $\mathrm{S}$, Kondoh $\mathrm{H}$, Hamada $\mathrm{H}$ : lefty-I is required for left-right determination as a regulator of lefty-2 and nodal. Cell 1998, 94(3):287-297. 
88. Ghaleb AM, Nandan MO, Chanchevalap S, Dalton WB, Hisamuddin IM, Yang VW: Kruppel-like factors 4 and 5: the yin and yang regulators of cellular proliferation. Cell Res 2005, I 5(2):92-96.

89. Funnell AP, Maloney CA, Thompson LJ, Keys J, Tallack M, Perkins AC, Crossley M: Erythroid Kruppel-like Factor Directly Activates the Basic Kruppel-like Factor Gene in Erythroid Cells. Mol Cell Biol 2007.

90. Wei D, Kanai M, Huang S, Xie K: Emerging role of KLF4 in human gastrointestinal cancer. Carcinogenesis 2006 27(I):23-31.

91. Bateman NW, Tan D, Pestell RG, Black JD, Black AR: Intestinal tumor progression is associated with altered function of KLF5. J Biol Chem 2004, 279( I3): I2093-12101.

92. Heyer LJ, Kruglyak S, Yooseph S: Exploring expression data: identification and analysis of coexpressed genes. Genome Res 1999, 9(II): II06-III5

93. Stepchenko AG, Luchina NN, Polanovsky OL: Conservative Val47 residue of POU homeodomain: role in DNA recognition. FEBS Lett 1997, 41 2(1):5-8.

94. Merika M, Orkin SH: DNA-binding specificity of GATA family transcription factors. Mol Cell Biol 1993, I 3(7):3999-40 I0.

95. Ovcharenko I, Nobrega MA, Loots GG, Stubbs L: ECR Browser: a tool for visualizing and accessing data from comparisons of multiple vertebrate genomes. Nucleic Acids Res 2004, 32(Web Server issue):W280-6.

96. Liaw L, Birk DE, Ballas CB, Whitsitt JS, Davidson JM, Hogan BL: Altered wound healing in mice lacking a functional osteopontin gene (spp I). J Clin Invest 1998, I0I(7): I 468- I478.

97. Luo J, Sladek R, Bader JA, Matthyssen A, Rossant J, Giguere V: Placental abnormalities in mouse embryos lacking the orphan nuclear receptor ERR-beta. Nature 1997, 388(6644):778-782

98. Rodda S, Sharma S, Scherer M, Chapman G, Rathjen P: CRTR-I, a developmentally regulated transcriptional repressor related to the CP2 family of transcription factors. J Biol Chem 200I, 276(5):3324-3332.

99. Rogers MB, Hosler BA, Gudas LJ: Specific expression of a retinoic acid-regulated, zinc-finger gene, Rex-I, in preimplantation embryos, trophoblast and spermatocytes. Development I99|, I I3(3):815-824.

100. Shi W, Wang H, Pan G, Geng Y, Guo Y, Pei D: Regulation of the pluripotency marker rex-I by nanog and sox2. J Biol Chem 2006, 28 I(33):23319-23325.

10I. Edgar AJ: Molecular cloning and tissue distribution of mammalian L-threonine 3-dehydrogenases. BMC Biochem 2002, 3:19.

102. Arima T, Hata K, Tanaka S, Kusumi M, Li E, Kato K, Shiota K, Sasaki $\mathrm{H}$, Wake $\mathrm{N}$ : Loss of the maternal imprint in Dnmt3 Lmat-/mice leads to a differentiation defect in the extraembryonic tissue. Dev Biol 2006, 297(2):36|-373.

103. Yoshikawa T, Piao Y, Zhong J, Matoba R, Carter MG, Wang Y, Goldberg I, Ko MS: High-throughput screen for genes predominantly expressed in the ICM of mouse blastocysts by whole mount in situ hybridization. Gene Expr Patterns 2006, 6(2):2। 3-224

104. Franz WM, Breves D, Klingel K, Brem G, Hofschneider PH, Kandolf R: Heart-specific targeting of firefly luciferase by the myosin light chain-2 promoter and developmental regulation in transgenic mice. Circ Res 1993, 73(4):629-638.

105. Tonini GP, Casalaro A, Cara A, Di Martino D: Inducible expression of calcyclin, a gene with strong homology to S- 100 protein, during neuroblastoma cell differentiation and its prevalent expression in Schwann-like cell lines. Cancer Res 1991, 5I(6): I733-1737.

106. Wang PJ, McCarrey JR, Yang F, Page DC: An abundance of $\mathbf{X}$ linked genes expressed in spermatogonia. Nat Genet 200I, 27(4):422-426.

107. Wulf $P$, Suter U: Embryonic expression of epithelial membrane protein I in early neurons. Brain Res Dev Brain Res 1999, I I6(2):169-180.

108. Ko MS, Kitchen JR, Wang X, Threat TA, Hasegawa A, Sun T, Grahovac MJ, Kargul GJ, Lim MK, Cui Y, Sano Y, Tanaka T, Liang Y, Mason S, Paonessa PD, Sauls AD, DePalma GE, Sharara R, Rowe LB, Eppig J, Morrell C, Doi H: Large-scale cDNA analysis reveals phased gene expression patterns during preimplantation mouse development. Development 2000, I27(8): 1737-1749.
109. Meno C, Takeuchi J, Sakuma R, Koshiba-Takeuchi K, Ohishi S, Saijoh Y, Miyazaki J, ten Dijke P, Ogura T, Hamada H: Diffusion of nodal signaling activity in the absence of the feedback inhibitor Lefty2. Dev Cell 200I, I(I): 127-I38.

1 10. Sakaguchi T, Nishimoto M, Miyagi S, Iwama A, Morita Y, Iwamori N, Nakauchi H, Kiyonari H, Muramatsu M, Okuda A: Putative "stemness" gene jam-B is not required for maintenance of stem cell state in embryonic, neural, or hematopoietic stem cells. Mol Cell Biol 2006, 26( I 7):6557-6570.

II I. Scott LM, Mueller L, Collins SJ: E3, a hematopoietic-specific transcript directly regulated by the retinoic acid receptor alpha. Blood 1996, 88(7):25।7-2530.

II2. Vogel W, Gish GD, Alves F, Pawson T: The discoidin domain receptor tyrosine kinases are activated by collagen. Mol Cell 1997, I(I): I3-23.

I I3. Mootha VK, Bunkenborg J, Olsen JV, Hjerrild M, Wisniewski JR, Stahl E, Bolouri MS, Ray HN, Sihag S, Kamal M, Patterson N, Lander ES, Mann M: Integrated analysis of protein composition, tissue diversity, and gene regulation in mouse mitochondria. Cell 2003, II 5(5):629-640.

I I4. Wassarman KM, Lewandoski M, Campbell K, Joyner AL, Rubenstein JL, Martinez S, Martin GR: Specification of the anterior hindbrain and establishment of a normal mid/hindbrain organizer is dependent on Gbx2 gene function. Development 1997, 1 24(15):2923-2934.

I15. Ikonomidis JS, Gibson WC, Butler JE, McClister DM, Sweterlitsch SE, Thompson RP, Mukherjee R, Spinale FG: Effects of deletion of the tissue inhibitor of matrix metalloproteinases-I gene on the progression of murine thoracic aortic aneurysms. Circulation 2004, I I (I I Suppl I): II268-73

I16. Katz JP, Perreault N, Goldstein BG, Lee CS, Labosky PA, Yang VW, Kaestner $\mathrm{KH}$ : The zinc-finger transcription factor KIf4 is required for terminal differentiation of goblet cells in the colon. Development 2002, I29(II):2619-2628.

117. Shindo T, Manabe I, Fukushima Y, Tobe K, Aizawa K, Miyamoto S, Kawai-Kowase K, Moriyama N, Imai Y, Kawakami H, Nishimatsu H, Ishikawa T, Suzuki T, Morita H, Maemura K, Sata M, Hirata Y, Komukai M, Kagechika H, Kadowaki T, Kurabayashi M, Nagai R: Kruppellike zinc-finger transcription factor KLF5/BTEB2 is a target for angiotensin II signaling and an essential regulator of cardiovascular remodeling. Nat Med 2002, 8(8):856-863.

I I8. Falender AE, Lanz R, Malenfant D, Belanger L, Richards JS: Differential expression of steroidogenic factor-I and FTF/LRH-I in the rodent ovary. Endocrinology 2003, I44(8):3598-3610

119. Vasseur S, Hoffmeister A, Garcia-Montero A, Barthet M, Saint-Miche L, Berthezene P, Fiedler F, Closa D, Dagorn JC, lovanna JL: Mice with targeted disruption of p8 gene show increased sensitivity to lipopolysaccharide and DNA microarray analysis of livers reveals an aberrant gene expression response. BMC Gastroenterol 2003, 3:25

120. Xu H, Gonzalo JA, St Pierre Y, Williams IR, Kupper TS, Cotran RS, Springer TA, Gutierrez-Ramos JC: Leukocytosis and resistance to septic shock in intercellular adhesion molecule I-deficient mice. J Exp Med 1994, I 80(I):95-109.

121. Kobayashi K, Hernandez LD, Galan JE, Janeway CA Jr., Medzhitov R, Flavell RA: IRAK-M is a negative regulator of Toll-like receptor signaling. Cell 2002, IIO(2):19I-202.

122. McGowan KM, Coulombe PA: Onset of keratin 17 expression coincides with the definition of major epithelial lineages during skin development. J Cell Biol 1998, I43(2):469-486.

123. Schubart UK, Yu J, Amat JA, Wang Z, Hoffmann MK, Edelmann W: Normal development of mice lacking metablastin (PI9), a phosphoprotein implicated in cell cycle regulation. J Biol Chem 1996, 27 I(24): | $4062-\mid 4066$.

124. Takahashi Y, Dominici M, Swift J, Nagy C, Ihle JN: Trophoblast stem cells rescue placental defect in SOCS3-deficient mice. | Biol Chem 2006, 28 I ( 7 7): I | 444- I I 445.

125. Jin W, Broedl UC, Monajemi H, Glick JM, Rader DJ: Lipase H, a new member of the triglyceride lipase family synthesized by the intestine. Genomics 2002, 80(3):268-273.

126. Ishiguro H, Furukawa Y, Daigo Y, Miyoshi Y, Nagasawa Y, Nishiwaki T, Kawasoe T, Fujita M, Satoh S, Miwa N, Fujii Y, Nakamura Y: Isolation and characterization of human NBL4, a gene involved in the beta-catenin/tcf signaling pathway. Jpn J Cancer Res 2000, 9 I(6):597-603. 
I27. Jiang N, Wang X, Jhanwar-Uniyal M, Darzynkiewicz Z, Dai W: Polo box domain of Plk3 functions as a centrosome localization signal, overexpression of which causes mitotic arrest, cytokinesis defects, and apoptosis. I Biol Chem 2006, 28 I(I5): I0577-10582.

128. Kim M, Geum D, Khang I, Park YM, Kang BM, Lee KA, Kim K Expression pattern of HSP25 in mouse preimplantation embryo: heat shock responses during oocyte maturation. Mol Reprod Dev 2002, 6 I (I):3-13.

129. Zhu M, Lovell KL, Patterson JS, Saunders TL, Hughes ED, Friderici $\mathrm{KH}$ : Beta-mannosidosis mice: a model for the human lysosomal storage disease. Hum Mol Genet 2006, I5(3):493-500.

130. Sato M, Kimura T, Kurokawa K, Fujita Y, Abe K, Masuhara M, Yasunaga T, Ryo A, Yamamoto M, Nakano T: Identification of PGC7, a new gene expressed specifically in preimplantation embryos and germ cells. Mech Dev 2002, I I 3(I):91-94.

|3I. Maki JM, Rasanen J, Tikkanen H, Sormunen R, Makikallio K, Kivirikko $\mathrm{KI}$, Soininen R: Inactivation of the lysyl oxidase gene Lox leads to aortic aneurysms, cardiovascular dysfunction, and perinatal death in mice. Circulation 2002, I06(19):2503-2509.

132. Sitzmann J, Noben-Trauth K, Kamano H, Klempnauer KH: Expression of B-Myb during mouse embryogenesis. Oncogene 1996 I 2(9): 1889-| 894.

133. Tang CJ, Lin CY, Tang TK: Dynamic localization and functional implications of Aurora-C kinase during male mouse meiosis. Dev Biol 2006, 290(2):398-4I0.

134. Beer HD, Bittner M, Niklaus G, Munding C, Max N, Goppelt A, Werner S: The fibroblast growth factor binding protein is a novel interaction partner of FGF-7, FGF-I 0 and FGF-22 and regulates FGF activity: implications for epithelial repair. Oncogene 2005, 24(34):5269-5277.

135. Razani B, Engelman JA, Wang XB, Schubert W, Zhang XL, Marks CB Macaluso F, Russell RG, Li M, Pestell RG, Di Vizio D, Hou H Jr., Kneitz B, Lagaud G, Christ G], Edelmann W, Lisanti MP: Caveolin-I nul mice are viable but show evidence of hyperproliferative and vascular abnormalities. J Biol Chem 200I, 276(4I):38I I I-38I38.

136. Beddington RS, Rashbass P, Wilson V: Brachyury--a gene affecting mouse gastrulation and early organogenesis. Dev Suppl 1992:157-165

137. Sun X, Meyers EN, Lewandoski M, Martin GR: Targeted disruption of Fgf8 causes failure of cell migration in the gastrulating mouse embryo. Genes Dev 1999, I3(14): 1834-1846.

138. Saga Y, Hata N, Kobayashi S, Magnuson T, Seldin MF, Taketo MM: MesPI: a novel basic helix-loop-helix protein expressed in the nascent mesodermal cells during mouse gastrulation. Development 1996, I 22(9):2769-2778

139. Behrens J, Jerchow BA, Wurtele M, Grimm J, Asbrand C, Wirtz R, Kuhl M, Wedlich D, Birchmeier W: Functional interaction of an axin homolog, conductin, with beta-catenin, APC, and GSK3beta. Science 1998, 280(5363):596-599.

140. Bouckson-Castaing V, Moudjou M, Ferguson DJ, Mucklow S, Belkaid Y, Milon G, Crocker PR: Molecular characterisation of ninein, a new coiled-coil protein of the centrosome. J Cell Sci 1996, 109 (Pt I): $179-190$

14I. Fehling HJ, Swat W, Laplace C, Kuhn R, Rajewsky K, Muller U, von Boehmer $\mathrm{H}$ : MHC class I expression in mice lacking the proteasome subunit LMP-7. Science 1994, 265(5 I 76): 1234-1237.

142. Cole TB, Wenzel HJ, Kafer KE, Schwartzkroin PA, Palmiter RD: Elimination of zinc from synaptic vesicles in the intact mouse brain by disruption of the $\mathbf{Z n T} 3$ gene. Proc Natl Acad Sci U S A 1999, 96(4): $17|6-172|$.

143. Meissner A, Zilles O, Varona R, Jozefowski K, Ritter U, Marquez G, Hallmann $R$, Korner $\mathrm{H}$ : CC chemokine ligand 20 partially controls adhesion of naive $B$ cells to activated endothelial cells under shear stress. Blood 2003, I02(8):2724-2727.

144. Li Y, Chambers J, Pang J, Ngo K, Peterson PA, Leung WP, Yang Y: Characterization of the mouse proteasome regulato PA28b gene. Immunogenetics 1999, 49(3): 149-157.

145. Ridley SH, Ktistakis N, Davidson K, Anderson KE, Manifava M, Ellson CD, Lipp P, Bootman M, Coadwell J, Nazarian A, Erdjument-Bromage H, Tempst P, Cooper MA, Thuring JW, Lim ZY, Holmes AB, Stephens LR, Hawkins PT: FENS-I and DFCPI are FYVE domain-containing proteins with distinct functions in the endosomal and Golgi compartments. J Cell Sci 200I, I I 4(Pt 22):399|-4000.

146. Ossendorp F, Fu N, Camps M, Granucci F, Gobin SJ, van den Elsen PJ, Schuurhuis D, Adema G], Lipford GB, Chiba T, Sijts A, Kloetzel PM,
Ricciardi-Castagnoli P, Melief C]: Differential expression regulation of the alpha and beta subunits of the PA28 proteasome activator in mature dendritic cells. J Immunol 2005, I 74(I 2):78|5-7822.

147. Mohan WS Jr., Scheer E, Wendling O, Metzger D, Tora L: TAFIO (TAF(II)30) is necessary for TFIID stability and early embryogenesis in mice. Mol Cell Biol 2003, 23(I 2):4307-43 I8.

148. Wagner DS, Gan L, Klein WH: Identification of a differentially expressed RNA helicase by gene trapping. Biochem Biophys Res Commun 1999, 262(3):677-684.

149. Shah GN, Ulmasov B, Waheed A, Becker T, Makani S, Svichar N, Chesler M, Sly WS: Carbonic anhydrase IV and XIV knockout mice: roles of the respective carbonic anhydrases in buffering the extracellular space in brain. Proc Natl Acad Sci U S A 2005, 102(46): 1677|-16776.

150. Lau YF, Chan KM, Sparkes R: Male-enhanced antigen gene is phylogenetically conserved and expressed at late stages of spermatogenesis. Proc Natl Acad Sci U S A 1989, 86(2I):8462-8466.

15I. Kusumi K, Sun ES, Kerrebrock AW, Bronson RT, Chi DC, Bulotsky MS, Spencer JB, Birren BW, Frankel WN, Lander ES: The mouse pudgy mutation disrupts Delta homologue DII3 and initiation of early somite boundaries. Nat Genet 1998, 19(3):274-278.

152. Spencer JA, Eliazer S, llaria RL Jr., Richardson JA, Olson EN: Regulation of microtubule dynamics and myogenic differentiation by MURF, a striated muscle RING-finger protein. I Cell Biol 2000, I50(4):77I-784.
Publish with BioMed Central and every scientist can read your work free of charge

"BioMed Central will be the most significant development for disseminating the results of biomedical research in our lifetime. "

Sir Paul Nurse, Cancer Research UK

Your research papers will be:

- available free of charge to the entire biomedical community

- peer reviewed and published immediately upon acceptance

- cited in PubMed and archived on PubMed Central

- yours - you keep the copyright

Submit your manuscript here:

http://www.biomedcentral.com/info/publishing_adv.asp
BioMedcentral 